\title{
Aporia in Umayyad Art or the Degree Zero of the Visual Forms' Meaning in Early Islam
}

\author{
Valerie Gonzalez \\ Research Associate, soAs, University of London \\ vg13@soas.ac.uk
}

\begin{abstract}
This article re-examines the established findings about Umayyad art as a transitional production essentially anchored in the Western and Eastern Late Antique traditions that have inspired it. It argues instead that the Umayyads brought about an aesthetic revolution laying out the foundations of what has become known as "Islamic ornament," a predominantly aniconic art form. An epistemological shift from art history to critical inquiry allows us to show that, beyond the adaptive borrowing of pre-existing forms, the Umayyads redefined the art's condition of meaning based on an unprecedented attitude to images and visual discourse informed by Islamic ontotheology and logocentric metaphysics.
\end{abstract}

\section{Keywords}

Umayyad iconography - Islamic ornament - ornamental theory - theory of meaning logocentrism - aporia - phenomenology - aesthetic philosophy - art criticism

Flat I see, then think distance, near, far, flat I see, east, back. JAMES JOYCE, Ulysses, 44

The present essay is at the crossroads of innovative trends within the broad field of Islamic and religious studies, in which I include the critical reflection on and by contemporary art practitioners engaging Islam in one way or another. Three events in particular illustrate these trends. The first event is a presentation given by the artist Shehzad Dawood on 6 July 2020, "Metissage, the Contrapuntal and Heterotopia," the last in an online series on Pluralism and Plurality in Islamic Cultures, co-produced by The Aga Khan University Institute for the Study of Muslim Civilizations, the Aga Khan Museum, and the Aga Khan Trust for Culture Education Programme. In this lecture, Dawood expounded his creative practice's source material gathering diverse references and thinking models. In his thought, timely humanistic themes, from Islam past and 
present, Sufism, postcoloniality to emigration, cross-fertilise with concepts drawing from twentieth and twenty-first century Western philosophy, art, and theory, by means of which he articulates his ideas and turns them into multimedia artworks. ${ }^{1}$

The second event is the emergence, in the mid-nineties, of Islamic religious studies combining the established methods of the period texts' hermeneutics and philology with the use of and comparison with various critical models borrowed from this same contemporary Western intellectual culture. ${ }^{2}$ In 2004, in Sufism and Deconstruction, Ian Almond wrote: "Over the past fifteen years, scholars from comparative religion and theology departments around the world have been rediscovering in their own religious traditions various precedents for Derrida's deconstructive writings ... Figures such as Pseudo-Dionysius, Meister Eckhart, Sankara, Lao-Tzu and Ayn al-Qudat Hamadani have all been credited with deconstructing the rigid logocentric assumptions within their own respective faiths, rescuing a more authentic spirituality from the legalistic metaphysics of their times." ${ }^{3}$

At last, the third event concerns the material turn of religious studies in general that unprecedently engage aesthetics. As David Morgan explains, "because embodiment and materiality comprise lived religion and therefore make sensation and feeling the media of belief, we may regard aesthetics as a primary framework for the study of religion." 4 Here "aesthetics" refers not only to culturally embedded and historically circumscribed theories of beauty and perception, that we may call "primary aesthetics" by association with primary sources, but also to the contemporary Euro-American aesthetic philosophies. ${ }^{5}$ Attending to all aspects of sensory prehension in Western culture and beyond, these philosophies are applicable to the study of any area and period material. They constitute advanced critical tools useful for the understanding of concepts, phenomena, and processes that the sole use of primary aesthetics cannot achieve. Phenomenology, process philosophy, or the Deleuzean theory of sensation are just a few examples of this vast theoretical corpus amenable to a global scholarly multiuse. ${ }^{6}$

Thus, together with this essay, these scholarly trends share an open epistemology founded on an ideology-free intermixing of canonical methods of inquiry with transculturally usable instruments of contemporary Western thought. However, such an epistemology has yet to settle in the sub-field of the history of Islamic art before the Modern and contemporary era to which this essay's topic belongs: Syrian Umayyad art (40/661-132/750). If this scholarship has embraced the material culture studies' theoretical discourses tackling issues of economy, sociology, and anthropology, it still massively resorts to traditional art history and primary aesthetics for the critical inquiry. ${ }^{7}$ Although valuable, the rare recent efforts to frame the study of historical Islamic art with a more up-to-date analytical apparatus remain unprepared and, consequently, seldom solve critical problems. ${ }^{8}$ The practice indeed requires more than glossing a few points with philosophical citations in arguments otherwise essentially relying on the conventional art historical method. ${ }^{9}$

This poor engagement with the contemporary critical corpus is not without consequences in the interpretation of Islamic art. Untenable readings of the material frequently stem from unchallenged old assumptions about the concepts at stake..$^{10}$ Particularly relevant for this study of Umayyad art are the persisting confusions between the distinct visual categories of decoration, ornament, figural patterning, and figurative representation. ${ }^{11}$ For, as we shall demonstrate, this art approaches these categories in an unprecedented manner in relation to their traditional use in the Late Antique heritage. In view of this scholarly background, a new epistemology of the subject and a terminological re-conceptualization are required prior to the investigation itself. 
This essay is premised upon the view that the conceptual foundations of what is known as "Islamic ornament," a predominantly aniconic art form, are the product of the Umayyads' processing of the Late Antique heritage of figurative representation in the regions they conquered from the Mediterranean to Persia. This means that, unlike Islamic art historians' wide assumption, these foundations did not plainly rely on an adaptive formal appropriation of the rich ornamental tradition also legated by this heritage, but on a much more complex approach to the Late Antique arts' condition of meaning centred on visual discourse and storytelling. A brief look into the collective volume Ornament and Figure in Graeco-Roman Art (2018) will clarify this point of the Late Antique arts' condition of meaning. ${ }^{12}$

In the presentation of this book aiming "to shed light on classical traditions of imagemaking by examining the rapport between 'ornament' and 'figure' in Graeco-Roman art," Michael Squire demonstrates that pattern repertoires actively participate in Graeco-Roman figurative constructs, noting that "the fundamental question that scholars have failed to ask is whether - and indeed how - categories of 'ornament' and 'figure' served to structure the ancient field of visual representation."13 This demonstration clearly underlines the Late Antique conception of art as fundamentally representational and narrative, ornaments and figures being both at the service of this conception. It is this art's condition of meaning focused on representation as an aesthetic metaphysics, not the formal binarities figure/ornament and figuration/abstraction themselves, that the Umayyads were concerned with and subverted in their appropriation of the pre-Islamic artistic models. In sum, instead of engaging the participation of ornament in the images' structure like in Late Antique art-making, the Umayyads did the opposite: they engaged the participation of images in ornamentalized structures. The novel art of Islamic ornament, I argue, emerged from this complex process.

However, to proceed with this argument an adequate definition of ornament is mandatory, considering that all the theories available on this concept spring from and reflect Western ornamental history. As James Massey notes: "we can recognize ornament in works from all times and places, but its nature and meanings change."14 In view of this fact, very few Islamic art historians have attempted to provide a neutral definition of ornament that would better serve the probing of its apprehension in Islam. ${ }^{15}$ The historiography invariably refers to the well-known ethnocentric Western problematizations of Islamic ornament, invariably lamenting their shortcomings. ${ }^{16}$ The following theoretical expose aims to fill this lacuna, in positing ornament in opposition to representation, not to figuration.

Visual Ontologies Revisited: Ornament versus Representation

To begin, a distinction must be made between the often interchangeable terms of 'ornament' and 'decoration' in the art histories. Decoration is the hypernym of ornament and of all the modes of visual expressions applied to and technically dependent on another medium, for example wall painting and tiling. These diverse sub-categories of decoration are not always confusable with ornament. Suffice it to mention the Raphael frescoes in the Vatican's papal complex that can be characterized as the stanze's "decoration," but not as their "ornaments." This simple observation points to ornament as being an aesthetic species that does not belong to the realm of representation understood as visual discourse, narration, or fiction. 


\subsection{General Properties of Ornament}

"Ornament," or "pattern art," presents the particularity of excluding all plastic manners that instrumentalize forms in order to achieve a fictional or discursive design. As Sharif Shukurov puts it, ornament "argues with nothing and disputes nothing."17 Such an instrumentalization is the prerogative of representation and other signifying visual expressions like "Conceptual Art." For unlike representation that only exists in the binding relationship between the representing object and what it represents, ornament ontologically is and primarily operates as a self-contained "structure" in the structuralist/post-structuralist sense of the word. As such, ornament is aesthetically autonomous, even though technically it is affixed to an artistic medium with which it builds some kind of relationship.

A structure consists of a formal assemblage of elements self-defined by their objective constitution, independently of any meaning this assemblage may convey. As Jacques Derrida explains, "the relief and design of structures appears more clearly when content, which is the living energy of meaning, is neutralized. Somewhat like the architecture of an uninhabited or deserted city, reduced to its skeleton by some catastrophe of nature or art." ${ }^{18}$ In this sense, ornament is a kind of skeleton, but it does not require any kind of content to be fully functional as its workings mostly rest upon the organizational properties of its morphological constitutive elements, namely form, space, colour, surface, line, texture, etc. Derrida, again, underscores this specific functioning of structure in the concreteness of its morphological organization when he says that, "within structure there is not only form, relation, and configuration. There is also interdependency and a totality, which is always concrete."19 Thus, pertaining to the world of non-fictional aesthetic structures, ornament fundamentally addresses the senses and makes sense through an enhanced sense-sensation of things, including the perceptual feeling of beauty. It is an affective transformative operatory device in the sense that it transforms the medium's aesthetic phenomenology, channelizes the artistic communication, and affects the art reception through its sensory properties. Crucially, it does all that without the aid of discourse. ${ }^{20}$ An example of ornament fitting this description is the transformative, yet non-signifying golden frame in classical European painting; the experience of paintings is not the same with and without it.

Furthermore, because of its structural ontology, ornament cannot dissolve itself in another construct outside of itself, as representation does through the blending of the representing (the representational structure) with the represented (the referents, the representation itself). This does not mean, however, that to be a genuine ornamental form, and not a representation, ornament must keep out any external meaning or cannot signify or refer to something external in the absolute. Ornamental art does have the capacity to foster some kind of content, but only in a very specific condition of meaning strictly preserving the primacy of structure and its aesthetic workings in both the artistic constitution and communication. This condition is of a symbolic-signaletic order, so that the ornament's content can only take on the abstract, generic, or reduced form of a code. Consequently, there exist two ornamental categories: non-signifying or a-referential mute ornament, and referential symbolic or encoded ornament. ${ }^{21}$

\subsection{Symbolic or Encoded Ornament}

Symbols, be they iconographic or aniconic, abound in many global ornamental arts. For example, signs-forms called "clan designs" appear on some African patterned textiles worn as encoded bodily ornaments, or decorate the hollow painted log coffins in Aboriginal art as evocations of specific ancestors. ${ }^{22}$ These carriers of meaning deliver what I would call a "compressed discourse," pre-assimilated collectively and understood 
FIGURE 1

Capilla de San Bartolomé, built against the tenth-century Qibla wall, Mosque-Cathedral of Cordoba, Spain

PHOTO: JOAN GGK (CC BY 2.0)

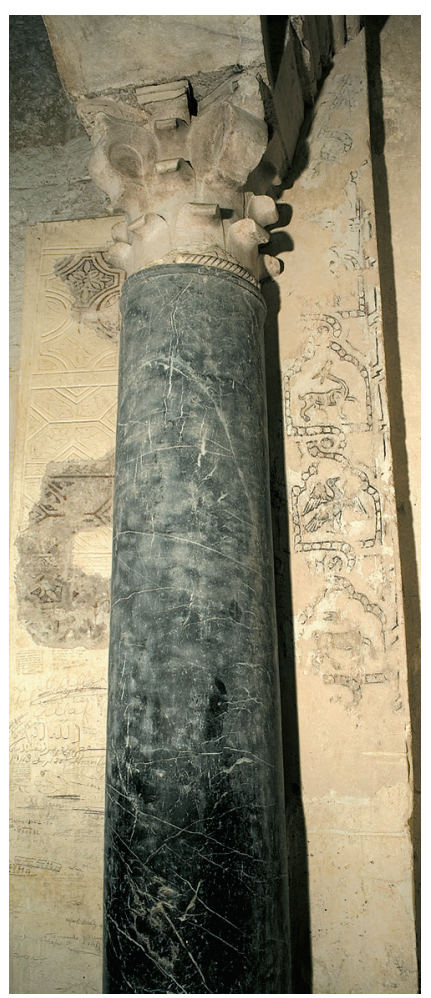

FIGURE 2

Umayyad column and figurative paintings, left side of the Capilla de San Bartolomé, Mosque-Cathedral of Cordoba PHOTO: COURTESY OF JOSÉ MIGUEL PUERTA VÍLCHEZ AND NIETO CUMPLIDO

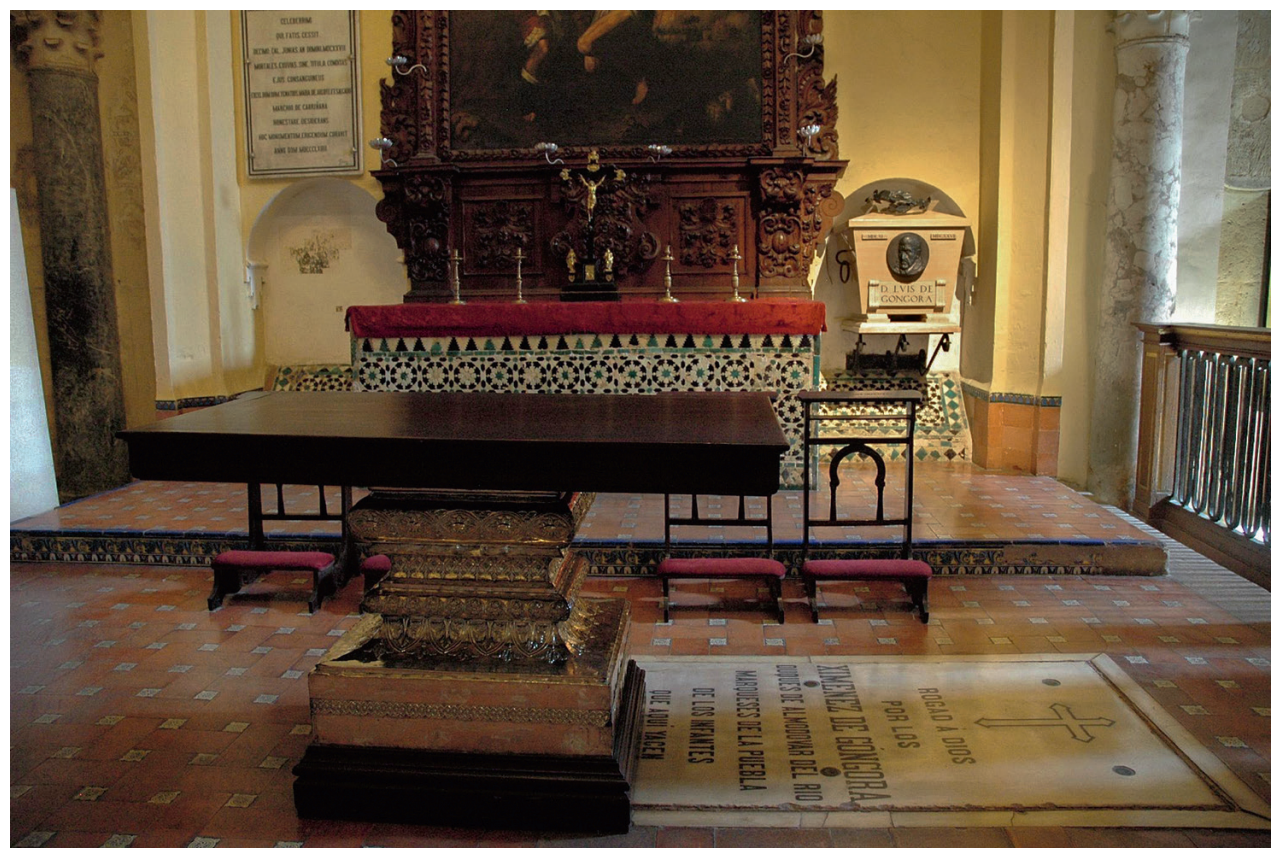

by flash recognition in the immediacy of the act of seeing. This type of semantic has no competence to overflow the ornament's structure, mask its "relief and design," and negate its ornamental identity by turning it into a discursive device. Therefore, in the aesthetic mechanisms of the ornamental configurations with symbolic values or a signaletic encoded system of meaning production, the subjectivities of the reference do not compromise the objectivity of the structure's primacy. In other words, in the phenomenology of such configurations, the phenomenological horizon remains the concrete sensory realm of hyle (matter). ${ }^{23}$ In short, symbolic ornament is ornament, and not representation, because it lets the senses control and subjugate sense.

Within the spectrum of ornamental symbols, the figural signs pose particular problems of interpretation. For the distinction between iconographic ornament and figurative or symbolic representation can sometimes be thin or blurred, at least in appearance, although they significantly differ from one another by establishing different communicative situations and by aiming to achieve different aesthetic-cognitive goals. As we shall see soon, Umayyad art is a case in point in this respect. Thus, while figural ornament significantly impairs, reduces, or neutralizes its iconographic repertoire's capacity of deporting the mind out of the forms' material objectivity, by contrast, genuine representation exploits this capacity. Simply put, a figural or iconographic ornament keeps the viewer's focus on its perceptual plastic properties, despite the references it may activate.

Diverse plastic strategies may produce the ornamentalization of iconography, such as the abstraction of the forms' representational properties through form flattening, stylization and patterning, or the immersion of images in an aesthetic environment, suppressing or severely tempering their intrinsic referential power. A striking example of iconographic ornamentalization by immersion in such an environment can be observed in the Umayyad Mosque of Cordoba, where Spanish scholars have uncovered figurative paintings on al-Hakam's Qibla wall (tenth century). Zoomorphic figurations of Sasanian style, similar to some painted decorations in Umayyad domestic architecture, appear behind a column on a portion of the wall that was spared by the Christian construction of the Capilla de San Bartolomé, the chapel in which the Spanish Baroque poet Luis de Góngora y Argote is buried. ${ }^{24}$ (Figs. 1-3) In this case, the de-semantization 
of the iconography takes places through both the figurations' repetition ad infinitum in the form of a vertical garland, and the placement on the Qibla wall where zoomorphic representation loses all signifying power. Thus, morphed into an asignifying repertoire, this iconography assumes the role of figural ornament, as opposed to figurative representation. As such, it enriches the aniconic ornaments of the mihrab and Qibla wall whose original state, we ought to imagine, most likely displayed more extensive ornamental figurations.

Owing to the suppression of their representational property, these Andalusi zoomorphic motifs and, by extension, any similarly muted figural ornamentation, belong to the second category of non-symbolic mute ornament. In this respect, these image-bearing ornamentations are no different from the purely aniconic patterns.

\subsection{Mute Ornament}

Mute ornaments can actually be abstract or concrete. The category of abstract ornament includes not only these patterned figural motifs in the Umayyad Mosque of Cordoba, but also the vegetal arabesques and flower bands in the gold mosaics decorating al-Hakam's mihrab and, to mention another example, the Ottoman tiling's floral designs. ${ }^{25}$ On the other hand, geometric networks like the mosaic parterres in the Umayyad palace of Khirbat al-Madjar (Fig. 4) or the ceramic wall decoration in the Alhambra fit the second category of concrete ornament. The difference is subtle, but non-trivial, because it affects both the ornaments' operatory mode and their perception by the viewer, depending on whether they are concrete or abstract. To explain this difference, one must turn to the history of plastic abstraction in the West, the inventor and theorist of the concept (obviously not of the practice itself).

Abstraction basically means the processual removal of representation in the artistic construct through a stepped plastic transformation from figure to shape, to pure materiality. In Western art history, the spectre of representation haunted abstraction in a seemingly unbreakable dialectical circularity, until finally artists got rid of this spectre and broke this circularity by eliminating abstraction itself through a return to the forms' pure concreteness. The latter indeed had been overlooked and undervalued in Western aesthetics due to the centrality of this tense dialectic between representation and abstraction in this aesthetics' normative system, and to the entrenched principle that art must signify or project something. Thus, while Mark Rothko and Barnett Newman's

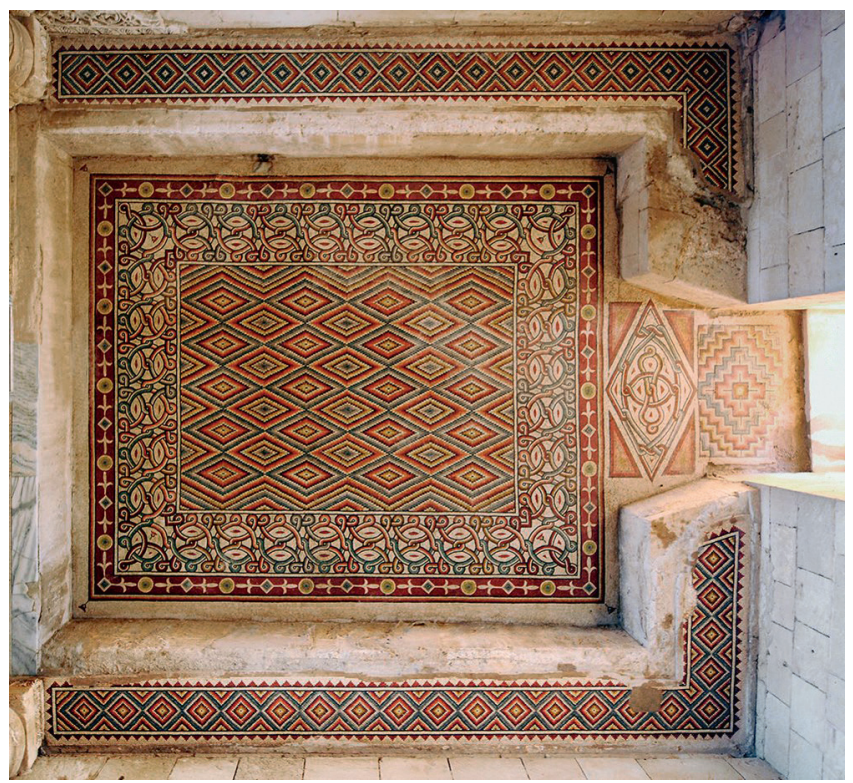

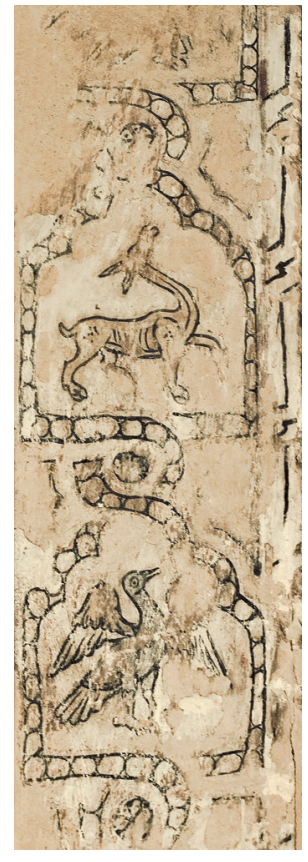

FIGURE 3

Detail of the Umayyad figurative paintings, Mosque-Cathedral of Cordoba PHOTO: COURTESY OF JOSÉ MIGUEL PUERTA VÍLCHEZ AND NIETO CUMPLIDO
FIGURE 4

Khirbat al-Mafjar, mosaic floors, palace of Hisham ibn Abd al-Malik (r. 105-125/724-743), Jericho, Jordan Valley PHOTO: COPYRIGHT (C)2016 ARAMCOWORLD 
paintings fall under the sign of abstract art (Abstract Expressionism), this attributive adjective is no longer required and actually inept to describe Minimalist works like Donald Judd's "Specific Objects" or Ellsworth Kelly's colour fields, as they pushed non-representational art beyond abstraction, into the region of pure objecthood. ${ }^{26}$ The movement Concrete Art in the thirties illustrates this artistic struggle that led to this evolution of non-representational art in the West in the second half of the twentiethcentury. As Sol LeWitt's "Geometric Structures" or John Cage's "Micro-Macrocosmic Rhythmic Structures" spell it out, the fulcrum of these aesthetic strategies beyond abstraction is the primal ontology of art as "structure."

Similarly, mute ornaments operate conceptually along these two lines of the nonrepresentation: some ornaments, abstract representation form the forms with a representational capital, like the stucco decorations in Samarra's palaces, whereas others build designs with no relation whatsoever to a representational source material. ${ }^{27}$ In this light, Islamic geometric designs appear quintessentially concrete. These descriptions now bring to the fore a last theoretical question to address: that of the nonsymbolic asignifying ornaments' meaning.

There exis two variants of asignifying ornaments: mute and decorative ornament or pure décor. Apart from the fact that both variants affect the art's constitution and reception, the crucial difference between the two lies in the scope of their cognitive objectives that only a critical analysis of their condition of meaning can determine. While the objectives of pure décor are essentially restricted to the sake of aesthetic materialism, mute ornament outreaches this objective and engages a complex logic of sense. For example, under certain secular conditions and aspects, Rococo design falls under the sign of pure décor. By contradistinction with the latter, mute ornaments play with what Derrida names "nonmeaning." 28

Nonmeaning means "nondiscourse," silence, or the absence, in the sense of nonpresence, of meaning, not the lack thereof. A metaphysical concept in the sphere of sense, nonmeaning is not to be equated with meaninglessness. It resides in the before, outside or beyond of signification, a region of sense in which meaning may just constitute an unactualized potentiality or remains latent. Nonmeaning may also emerge from an intentional renunciation, sacrifice or erasure of meaning like in Minimalist thought. In short, "nonmeaning" is non-signified or eradicated meaning. In philosophy and aesthetics, aporia, sublation in the Hegelian sense, and the Merleau-Pontian "hyperdialectic" produce nonmeaning. ${ }^{29}$ While aporia blocks meaning and thereby creates the absence or quasi-absence of meaning, spectral meaning or residual meaning, sublation and the hyperdialectic mainly enable the suspension of meaning by the dialectic. ${ }^{30}$

In art, these processes purify the work's structure from content or minimize the latter to the least possible, in order to let the forms exert the force of their perceptual phenomenality. Examples of sublation and hyperdialectic may be found in Abbasid decorations such as wood carvings in which images of birds or other animals fuse with sinuosities. This fusion challenges the images' figural ontology and incapacitates their referential power, thereby creating a situation of nonmeaning or suspended meaning. In Western culture, aporetic creations include James Joyce's reduction of wordings to phoneticism and Michelangelo Frammartino's abolition of the human voice and plot in his film Le Quattro Volte. It is also an aporetic act that the Irish actor Stephen Rea was asked to perform by Samuel Beckett, as he reported in an interview: "I asked him what a line meant and he said: 'Don't think about meaning, think about rhythm.'”1 
Regardless of genre, in the arts nonmeaning takes on essentially three forms: a silent field of possibilities for meaning to constitute itself, like in Clyfford Still and Mark Rothko's paintings; a quasi-silent field inhabited by residual or spectral meanings, like in Willem de Kooning's and Lee Krasner's paintings; a pure absence laying bare the artistic structure from which meaning has been consciously neutralized, like in some Abbasid architectural decorations, or squarely banned in the pursuit of art as a pure objective-concrete presence, like in Minimalist art. In the sonic domain, John Cage's compositions and Frank Zappa's "musique concrète" equally "have nonmeaning."

Gathering all these cases theoretically defined, the heterogeneous Umayyad architectural decoration raises issues of characterization, categorization and hermeneutics. Do the bejewelled iconographic mosaics of the Dome of the Rock constitute symbolic ornaments or mute patterns by sublation of their representational discourse? (Fig. 5) Are the landscape-cityscape mosaics of the Great Mosque in Damascus representations or aporetic iconographic forms? (Figs. 6-7) Addressing these questions requires an introduction to the Umayyad intellectual context, which tends to be neglected in art historical studies.

\subsection{Islamic Logocentrism: The Condition of Umayyad Aporetic Art-Making}

As we know, the Umayyads appropriated the multicultural pre-Islamic artistic heritage out of both necessity and appreciation. However, this appropriation put them in a situation of aesthetic-philosophical violence and conflict of interest because this heritage could not adequately translate their own Islamic metaphysics characterized by an unprecedented form of logocentrism. ${ }^{32}$ The Umayyad artistic creativity springs from their dealing with this tense paradoxical situation. And this creativity, I contend, resides in the engagement of aporia as the new Islamic condition of meaning in visuality, in line with Islam's logocentric metaphysics; the most discussed issue of a restrictive figurative representation is only a consequence of this state of affairs, not its cause. ${ }^{33}$

"Logocentrism" is an age-old Western concept referring to the centrality of the logos, namely language as the compound of speech, thought, and writing, in the philosophical quest for understanding the world and its origin. ${ }^{34}$ In Western philosophy, the logocentric methods and discourses rest upon a metaphysics of presence/absence, namely a certain conceptualization of "what is and what is not." It is in the sense of a logosfounded thought system that logocentrism concerns Islam, the metaphysics of presence/absence merging with the Islamic metaphysics of the seen and the unseen. But if Western logocentrism is the mutable product of human thought, by contrast, Islamic logocentrism emanates from the divine order dictated by God's sacred supernatural speech written down in the Quran. Therefore, Islamic logocentrism constitutes an absolute pre-given. ${ }^{35}$ Moreover, not only does this pre-given attributes the primacy to speech, sound, and aurality without human consent, but also, by virtue of God's omnipresence and omnipotence, it locates the world's origin in an incommensurable expansion engulfing the mundane and the beyond-it in consubstantiality and indivisibility. Simon O'Meara examines this question of origin in Islam in his illuminating study of the Kaaba as the nucleus of this consubstantiality. ${ }^{36}$

In my view, it is Derrida's critique of Western logocentrism, the famous deconstruction, that actually brings it closer to its Islamic counterpart. What Derrida does in deconstructing the main logocentric binaries of speech/writing, words/thought, and the signifier/the signified, is to point out the unthought absent meanings (nonmeanings) 


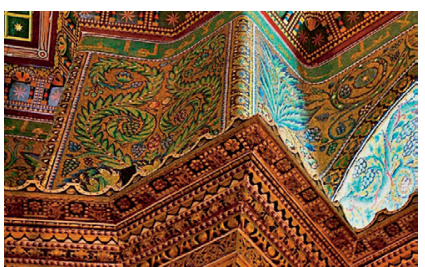

FIGURE 5

Dome of the Rock, built by Abd al-Malik, completed in 71/691, Jerusalem. View of the mosaics of the octagon's arches, with Kufic calligraphic band (photographer unknown) that surround them. He terms this unthought the "trace," as concisely explained in The Chicago School of Media Theory: "Derrida instead recognizes that any "present" sign will necessarily bear the trace of that which it is not: what it differs from, what it defers from, and that on which its presence is contingent." ${ }^{37}$ Relevantly for Islam, this Derridean trace opens up an infinitely expandable space of meaning in negative, an intuited absence not excluded from, but in relation to the positive presence of each binary's nucleus. That space can stretch up its limits to the unknown, ungraspable by reason, but sensed as a possibility; a beyond human thought some indeed may equate with the divine. In other words, the open system of the Derridean logocentric deconstruction envisages, in its particular intertwinement of presence and absence, the unfathomable that is the possibility of God. It thus makes the use of this system relevant in the study of logocentric spiritual contexts like Islam and Judaism for which God is unseeable and unrepresentable, especially in the study of Islamic art whose most original aesthetic developments are the pure product of Islamic logocentrism..$^{38}$

In Islam, indeed, God's words and human speech, thought, and writing channel one another in a linkage by trace in the Derridean sense. The listening, reciting, and writing/copying of the Quran form an indivisible channel of acts, all converging toward the eidetically present divine speech. By the same token, the very gesture of writing, regardless of content, materializes the trace of this channel, and so does ornamental calligraphy, with or without a religious content. From the Umayyad period onward, calligraphy was consequently bestowed with the sacralizing representational and discursive function in the Islamic visual field, as we may observe it in the Dome of the Rock's interior design. (Fig. 5) Such an order of things had logically the major consequence of rendering images unnecessary in the representation of the sacred in Islamic visuality. ${ }^{39}$ This non-necessity of the images, however, by no means implies that they were excluded, not used, or prohibited in the sacred aesthetic space. As we know, Islamic religious iconography includes, for example, the icon of the Kaaba and the imagery of the Prophet's miraj. Yet, while the latter mainly appear in precious illustrated books reserved to the elite, these images were/are not indispensable for the Muslim masses to live fully their pious life as the circuits of the sacred knowledge's transmission in Islam are of aural, verbal, and textual nature.

The phenomenological examination of the most representative Umayyad creations will demonstrate that this logocentric metaphysics-founded function of writing in Umayyad art-making led to the re-positioning of mute ornament at the centre of Islamic visuality, and that this re-positioning was effectuated by means of various aporetic manipulations of the imageries-filled Late Antique models.

\subsection{Aporetic Slidings in Qusayr 'Amra's Wall Paintings}

Scholars have well evidenced the stylistic and technical sources of the Umayyad architectural decorations drawing upon both the representational and abstract pre-Islamic repertoires of Graeco-Roman, Byzantine and Persian-Sasanian origin. However, they have been at pain to grasp the aesthetic transformations that turned these decorations into specifically Islamic expressions, due to their reliance on traditional art history previously critiqued. Particularly problematic is the unquestioned use of the style-based duality of representation versus abstraction, superimposing on Umayyad art the conceptual organization of the pre-Islamic visual regimes. Following this epistemic scheme, the Umayyad aniconic decorations inspired by Late Antique pattern art, like the geometric designs in the mosaic floors of Khirbat al-Mafjar or the vegetal interlacing adorning a multitude of objects and surfaces, are naturally viewed as the beginning of abstract Islamic ornament. (Fig. 4) In a parallel manner, the pre-Islamic representational logic is discerned in any imagery, figural ornaments and narrative 
figurations alike, in Qusayr 'Amra paintings like in the Mshatta facade. ${ }^{40}$ (Figs. 8-12) An assessment of the gold mosaics in Umayyad religious architecture epitomizes this problem: "For all their aniconism and culturally modified iconography, there is little in the Umayyad mosaics of either Jerusalem or Damascus that cannot be paralleled in the work of Byzantine mosaicists." 41

Yet, this "little" is precisely this unprecedented aporetic approach to the visual arts to be argued in this essay: a true artistic revolution in fact, that I call "the degree zero of the meaning of forms" in the newly Islamicized Mediterranean and Middle East. Although it is the least obvious instance of Umayyad aporetic aesthetics, Qusayr 'Amra's frescoes bear all the signs of this revolution.

In an enlightening article on these frescoes, Nadia Ali uncovered the Islamic adaptation of pre-Islamic narratives such as the story of Jonas and the whale, and the Nativity. ${ }^{42}$ The conversion of ancient imageries into Muslim representations in the context of nonreligious architecture is a most expected endeavour in this early Islamic period of art experimentalism, and in a cultural environment packed with ancient pre-Islamic aesthetic habits to be repurposed under the new faith-based rule. Thus, in Qusayr 'Amra some stories change, but not the manner of expression, figurative representation, or so it seems. (Figs. 8-10) In fact, when observed phenomenologically as the parts of a cumulative painted ensemble in the Late Antique manner, the Islamicized images and the other surrounding depictions appear crossed by an underlying conceptual counter-stream of a different nature that eclipses the first inkling of a mere Umayyad compliance with pre-Islamic representational modalities, regardless of their particular aesthetic evolution and shifts. ${ }^{43}$ Although the profuse iconography gives the impression of an eventful and loquacious narrative programme, it presents subtle albeit consistent slidings toward what we could term a "de-semantizing figural materialism." This process consists of an emphasis on the formal structural complexity of the images at the expense of their semantic content. It is, again, to be distinguished from the aestheticstylistic movements from mimesis to abstraction observed in Late Antiquity that, at a conceptual level, did not change a communicative situation and condition of meaning centred on figurality and discourse. Left unattended by a scholarship focused on iconographic deciphering, these Umayyad slidings are the product of precise compositional

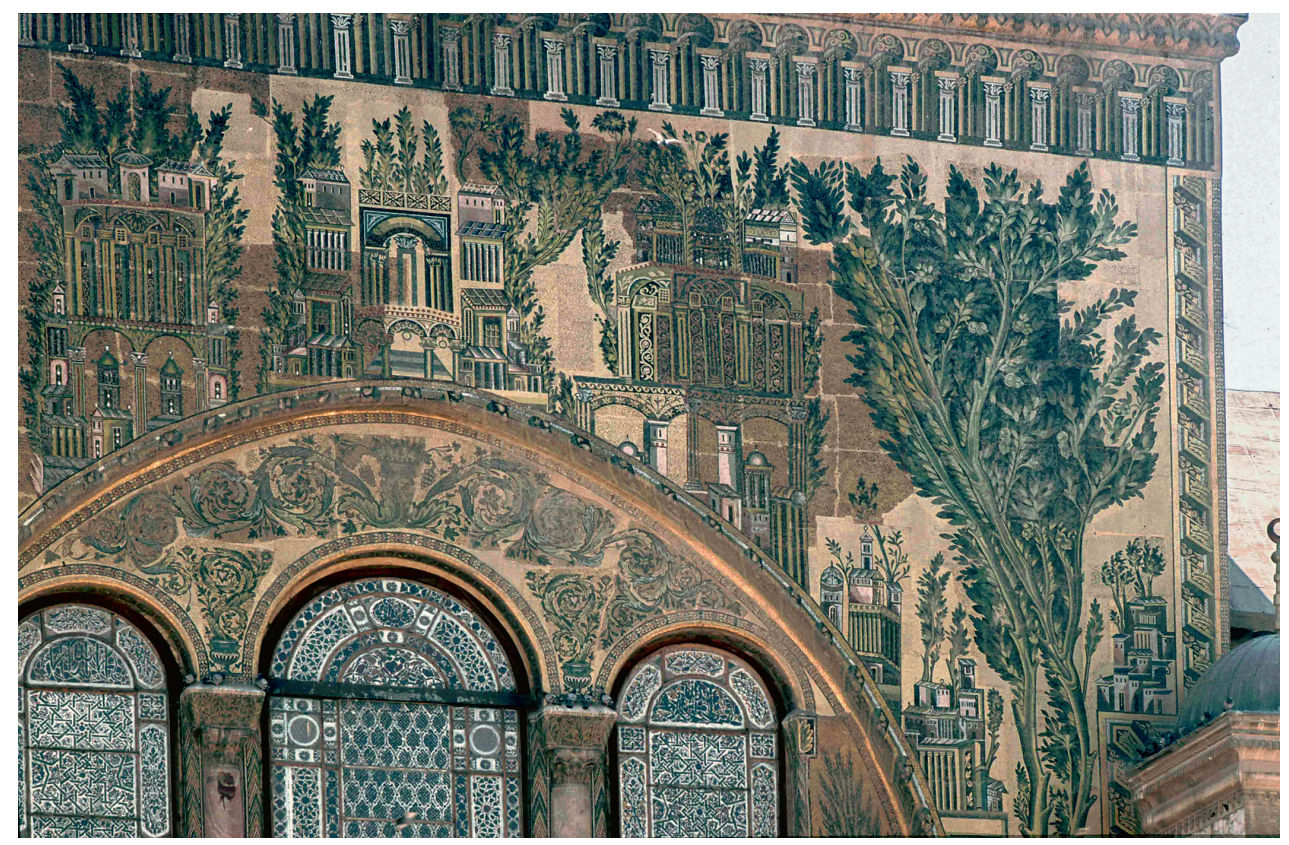

FIGURE 6

Great Mosque of Damascus, built between $86 / 705$ and $96 / 715$ by Al-Walid, mosaics on the pediment of the central nave's entrance PHOTO: COURTESY WADE ARCHIVE PATTERNINISLAMICART. COM 
FIGURE 7

Great Mosque of Damascus, mosaics on the Treasury, courtyard PHOTO: COURTESY WADE ARCHIVE PATTERNIN ISLAMICART.COM

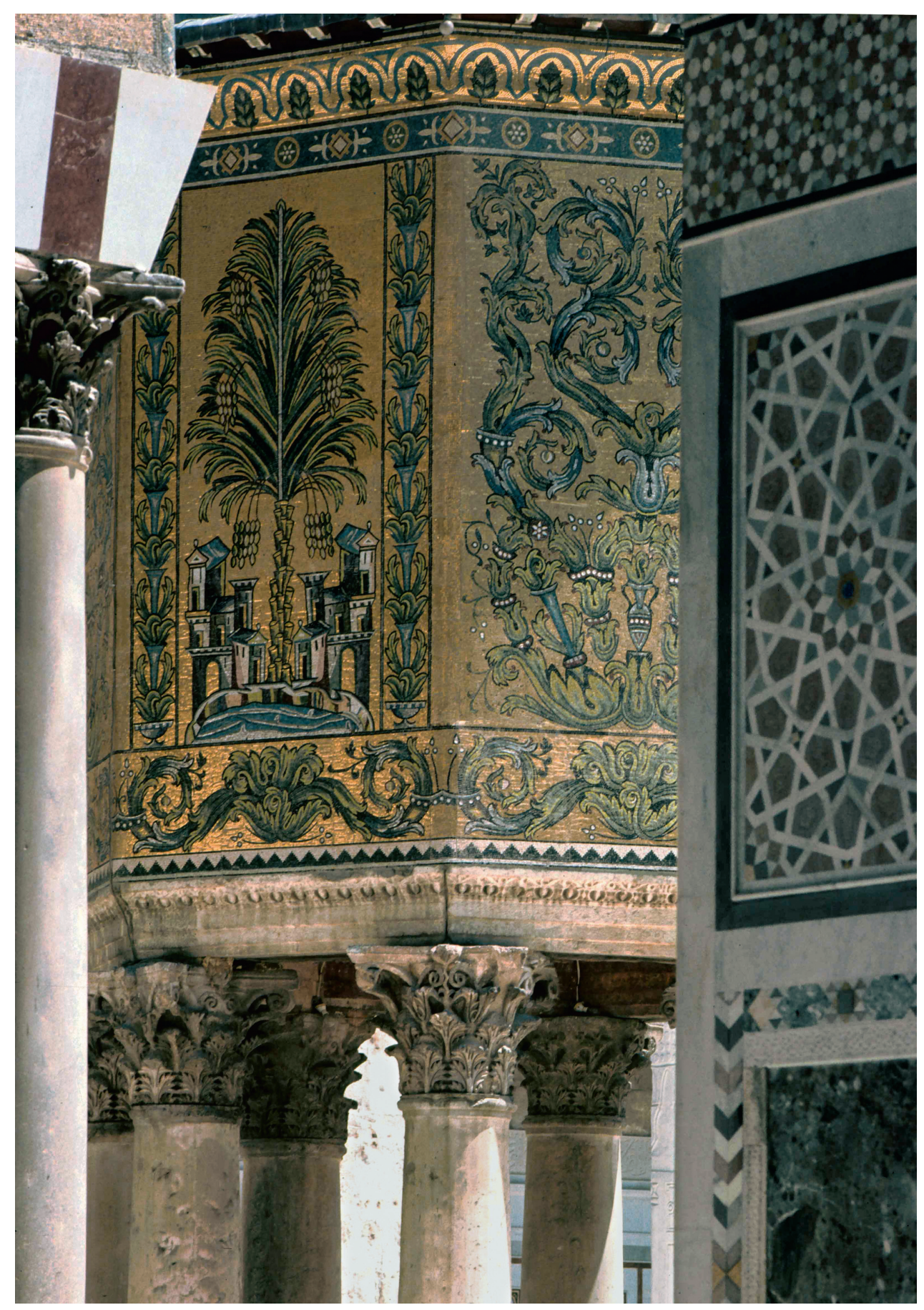

and stylistic features that unusually complexify, to not say opacify, the narrative unfolding throughout the pictorial cycles.

A first feature is the singular multidirectionality of the painted thematic, defying semantic cohesion and unsettling the seemingly unambiguous operations of representation assumed by the scholarship. Highly heterogeneous topics and stories, from the aforementioned Biblical-Quranic illustrations, leisure scenes, astronomic imagery, to kingly portraiture, are abruptly, if not incongruously, placed side by side like a pastiche with no apparent narrative focus. The religious illustrations thus coexist with lavish mundane hunting and bath scenes in a puzzling equality of aesthetic status. Beyond the symbiosis of the imageries with the architectural space, no specific semantic interest can be segregated in this eclectic aggregation of sacred and profane topics of ostensibly 
equal cognitive importance. In addition, the greatly varied size of the figures does not seem to correspond to a hierarchy of their semantic position in the narratives.

A second feature reinforces this reading of the paintings as aporetically inclined, that is the intensified ornamentalisation of the forms by comparison with the same phenomenon in the Late Antique models. While the latter always maintain a certain coherence of the narrative fabric despite the plastic-iconographic saturation, in Qusayr 'Amra this fabric appears edgily stretched out through the proliferation of framing devices and self-contained human and animal figurations with a loose thematic link, if at all, to the main scenes. The enlarged semi-naked female figure painted on an intrados typifies these figurations. (Fig. 10) In any event, most likely many of these peripheral imageries drawn from diverse Antique repertoires had no longer semantic pertinence or bore little significance for the Muslim beholders. Overall, while the relationship between structure and content in the Late Antique works continues to serve the art's visual discourse, the Umayyad disjunctive juxtaposition of heterogeneous scenes appears to subvert this order of things by setting the imageries' cognitivity in competition with their forms' aesthetic materialism. It is this competition that generates the conceptual aporetic slidings from representation to structure, and from the discursive to the ornamental that, in effect, challenges the traditional pre-Islamic conceptualization of iconographic art as the signifying system by excellence.

These slidings in Qusayr 'Amra signal a profound conceptual agitation, a tensionfilled oscillation between conflicting aesthetic interests and aspirations that I interpret in the following terms. If the Umayyads engaged with the ancient representational tradition, they also manifested their desire to break away from it as this tradition had no grip on the Umayyad-Muslim logocentric consciousness. To fulfil their logocentric needs while re-using pre-Islamic iconographic expressions, the Umayyads changed, to paraphrase Jacques Rancière, "the very distribution of the sensible that delimits the horizons of the sayable and determines the relationship between seeing, hearing, doing, making, and thinking." ${ }^{44}$ As said before, the Umayyad re-distribution of the artistic sensible bestowed calligraphy with the privilege of saying the Islamic sacred sayable in the most transparent terms of the verb, like in the Dome of the Rock or in the mihrab's decoration of the Mosque of Cordoba. (Fig. 5) As for the Umayyad conception of seeing and making, Qusayr 'Amra's paintings bespeak a strong conceptual attraction for materialistic visual structures, subtended by a distance vis-à-vis the Antique philosophy of the image as metaphysical mirror and cultural matrix. This phenomenon manifests itself more pronouncedly in the stone and stucco figures-bearing architectural decoration of the palaces of Mshatta and Khirbat al-Mafjar. (Figs. 11-12)

\subsection{The Muting of the Figural in Mshatta and Khirbat al-Mafjar}

While their aesthetic phenomenology places these decorations in the category of ornament, the possible existence of a symbolic content remains an unanswerable question in the absence of any period documentation. On Mshatta's lavish facade, flat animal figurations punctuate the geometrically organized jungle of swirling arabesques, like silent intervals between loud sonic compositions. In Khirbat al-Mafjar, kinetic series of human heads and friezes of animal motifs carved in high relief amidst dense traceries and vegetal profusions bring to mind the Renaissance "grotesque." Meaning seems plainly lost in this sublating hyperdialectics between figuration and configuration. Yet, speculations abound about the possible significations these various decorations might convey. Conceptually equating mute ornament with pure décor, scholars have been incessantly looking for explanations enabling them to ward off the spectre of the Orientalist view of a meaningless embellishment. With no other alternative than a referential interpretation of some kind, they lent these decorations a wide spectrum of

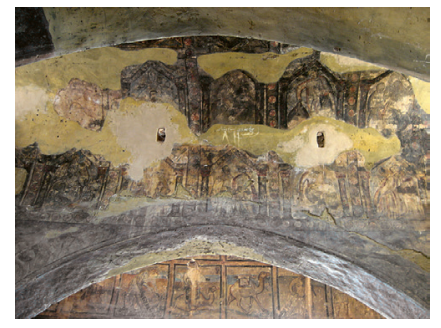

FIGURE 8

Qusayr 'Amra, frescoes in the audience hall, Jordan, early eighth century

PHOTO: (C)2005 FREDERIK QUESTIER AND YANNA VAN WESEMAEL, CREATIVE COMMONS ATTRIBUTIONNONCOMMERCIAL-SHAREALIKE 2.0 BELGIUM LICENCE

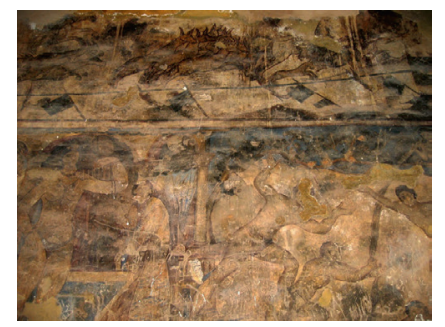

FIGURE 9

Qusayr 'Amra, fresco depicting hunting and bath scenes PHOTO: (C) 2005 FREDERIK QUESTIER AND YANNA VAN WESEMAEL, CREATIVE COMMONS ATTRIBUTIONNONCOMMERCIAL-SHAREALIKE 2.0 BELGIUM LICENCE

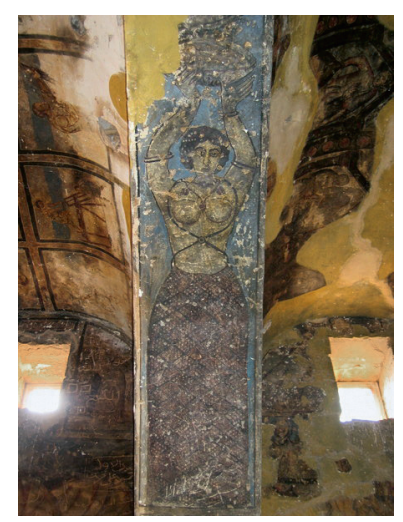

FIGURE 10

Qusayr 'Amra, bath, frescoes in the audience hall, Jordan, early eighth century

PHOTO: (C) 2005 FREDERIK QUESTIER AND YANNA VAN WESEMAEL, CREATIVE COMMONS ATTRIBUTIONNONCOMMERCIAL-

SHAREALIKE 2.0 BELGIUM LICENCE 
FIGURE 11

Qasr Al Mshatta, eighth century, Museum of Islamic Art, Berlin, Pergamon Museum

PHOTO: RAIMOND SPEKKING, CC BY-SA 4.0 VIA WIKIMEDIA COMMONS

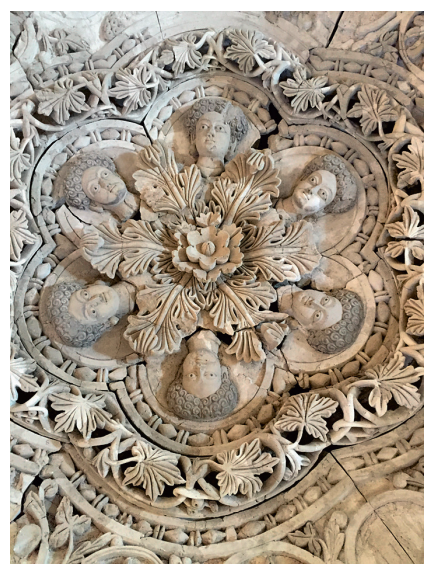

FIGURE 12

Khirbat al-Mafjar, palace of Hisham ibn Abd al-Malik, Jericho, Jordan Valley. Ceiling decoration in carved stucco. Rockefeller Archaeological Museum, Jerusalem PHOTO: SARA TOTH STUB/ COURTESY THE ROCKEFELLER ARCHAEOLOGICAL MUSEUM

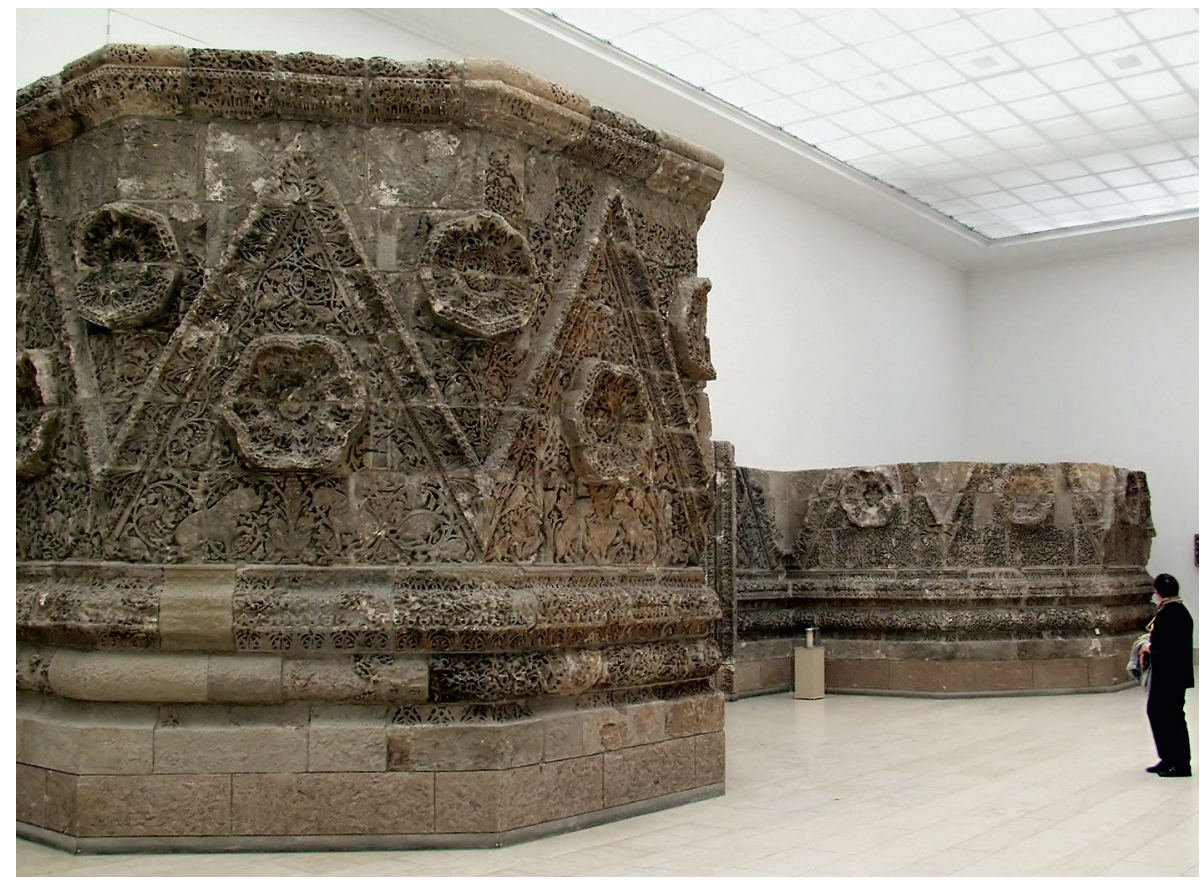

potential meaning ranging from portraiture, visions of the Quranic Paradise, a semiosis of political-religious triumph, to a metaphoric evocation of Solomonic mythology. 45

In my view, these are definitely ornamental works with no representational or symbolic content. They consequently pose the following questioning. Do the mute ornaments of Mshatta and Khirbat al-Mafjar fashion an indulgent, materialistic pure décor on a grand scale in the specific context of domestic architecture, and why not after all, or are they experiments signalling a novel conception of ornamental art as a site of nonmeaning? Actually, these two interpretive propositions are not mutually exclusive. As I see it, the decorative impulse in the Umayyad regal luxurious domestic environment served the pragmatics of a visual expression in the making apt to fulfil the Muslims' new aesthetic desires, namely an expression liberated from the pre-Islamic representational legacies and engaged in the exploration of the borrowed forms as pure structures. Presenting an analogous conceptual friction between image and structure, the mosaics of the Great Mosque in Damascus and of the Dome of the Rock contain clues that support this contention.

\section{Death of Meaning and Representation in Reprieve in the Mosaics of the Great Mosque in Damascus}

The mosaics of the Great Mosque of Damascus are the quintessence of the Umayyad vanguard art beyond signification. In accordance with Islamic ontotheology, there is no human or animal figuration in this decoration, yet, iconography dominates it. (Figs. 6-7 and 13) The source of the sprawling landscape-architecture imagery is Romano-Byzantine, but again the forms' configuring, their proportions, and their mode of occupation of the architectural medium do not conform with the pre-Islamic material's compositional criteria. Instead of producing vivid tableaux de nature like in Roman architecture, or informative renditions of edifices and cities like in Byzantine churches and palaces, the mute impenetrable Umayyad ensemble delivers an aporetic spectacle of "nowhereness" at a monumental scale, eluding all sense of spatiotemporality. 


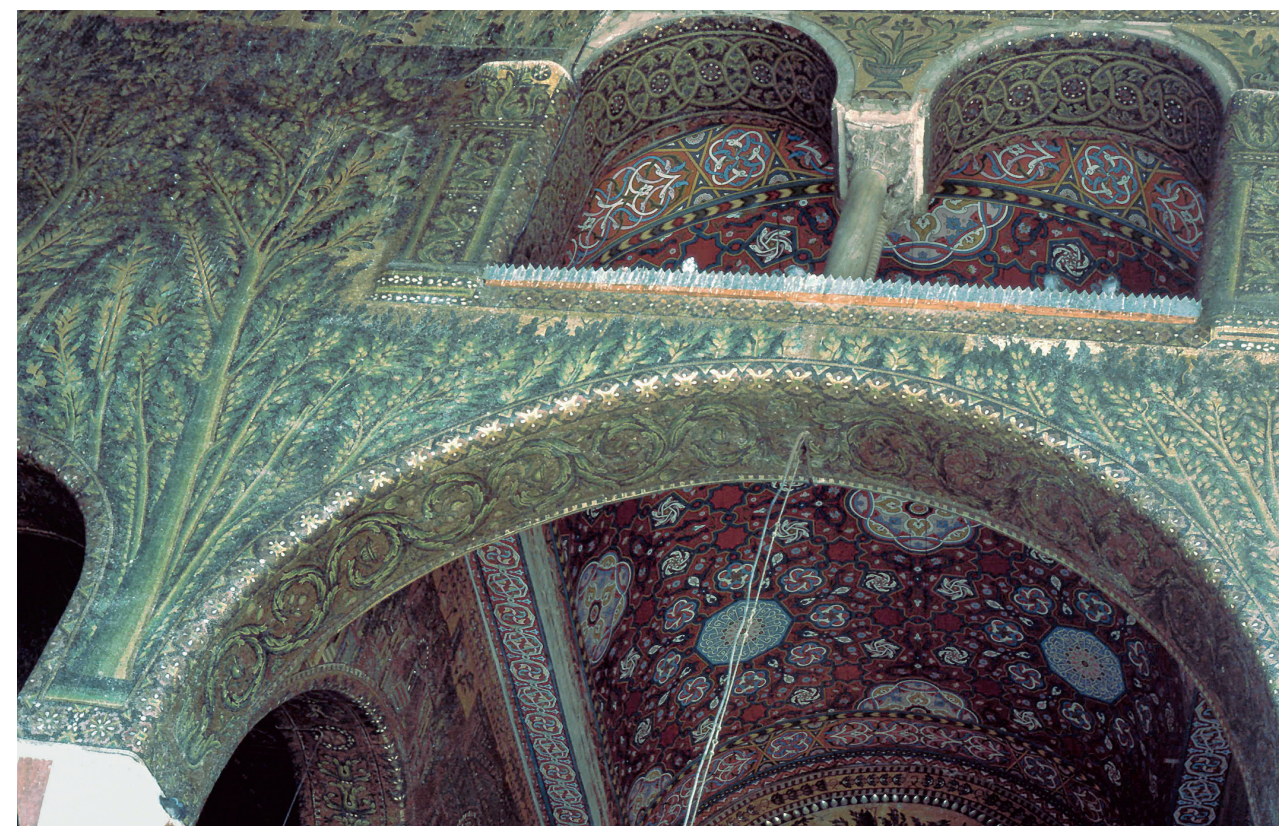

No names or any other visual clues are provided to enable the viewer to locate the places depicted and to identify the buildings represented, in sharp contrast with the Byzantine mosaics of the same genre exuding a sense of belonging, narrative unfolding, and territorial anchorage. The only iconographic element relatable to a concrete site was the Kaaba motif that, according to the sources, used to adorn the mosque's first mihrab. ${ }^{46}$ However, there is no indication whatsoever that this motif, as well as the original bands of calligraphy documented in the sources, had any semantic linkage with the ethereal leafy imagery displayed throughout the building. In sum, by contrast and counterpoint with the twofold device of the mihrab/Kaaba that physically inscribes the building in the tangible geographic-cosmological reality of the Muslim universe, the landscapearchitecture mosaics appear to construct an autonomous, self-defined, and unlocalized aesthetic space.

In phenomenological terms, the mosaic compositions abstract the iconography's mimetic properties so as to emphasize structural and patterning principles. The images' rhythmic organization, perceptible in the alternately repeated vegetal, architectural and aquatic themes, the symmetric motif distribution, and the antithetic or mirroring placement of the forms along axes, strongly accentuates the decoration's ornamental character. In addition, the iconographic motifs present haptic qualities that usually characterize the world of objects. ${ }^{47}$ For example, like the vegetal designs in Art Nouveau, the trees deploy their long branches into a limitless textile-like spreading of textured colours and sinuous lines organically fusing with the architecture. (Fig. 14) This fusion of the decorative forms with the architectural medium displaces the imagery's operatory aesthetic ground from fiction to structure. Analogously, some flat renditions of palaces with pearl motifs appear like monumental jewels in the shape of architecture inlaid into the building's surfaces. Clearly, this tension between image or fiction and structure is of the same nature as the aporetic slippages observed in domestic architecture. And as for the latter, we are confronted with both the medieval chronicles' apparent lack of explanation about the art's meaning and the scholarly speculation.

\subsection{Primary Textual Evidences and Scholarly Interpretations}

To summarize the primary sources' content, they basically describe the mosaics' iconography as we can still see it today with its display of castles, cities, villages, trees,

\section{FIGURE 13}

Great Mosque of Damascus, interior mosaics PHOTO: COURTESY WADE ARCHIVE PATTERNIN ISLAMICART.COM

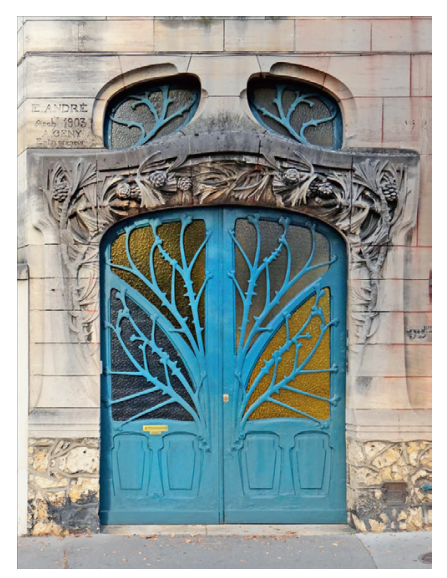

FIGURE 14.1

Art Nouveau entrance doors of three buildings

Entrance to the Maison Huot, 92-92bis quai, Claude Le Lorrain, Nancy, France. By architect Emile André (1903)

PHOTO BY JEAN-PIERRE DELBÉRA (CC BY 2.0) 
FIGURE 14.2

Doorway, No. 29 Avenue Rapp, Paris, France. By architect Jules Lavirotte (1901) PHOTO BY STEVE CADMAN (CC BY 2.0)

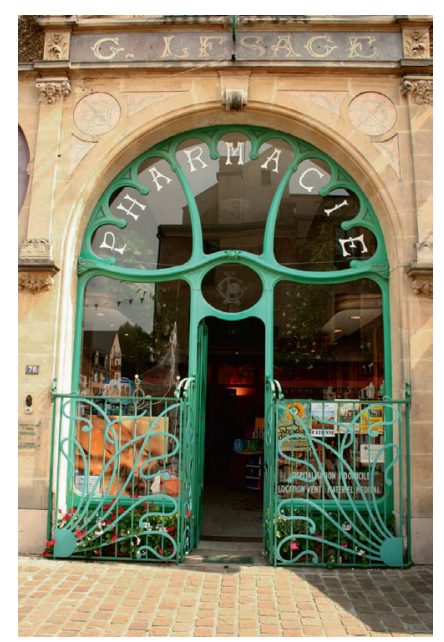

FIGURE 14.3

Chemist shop doorway

(Pharmacie Lesage) in

Douvres-la-Délivrand, Calvados,

Basse-Normandie, France. By

architect François Rouvray (1901).

Ironwork by Adolph Marie

PHOTO BY IAN PARKES

(CC BY 2.0)

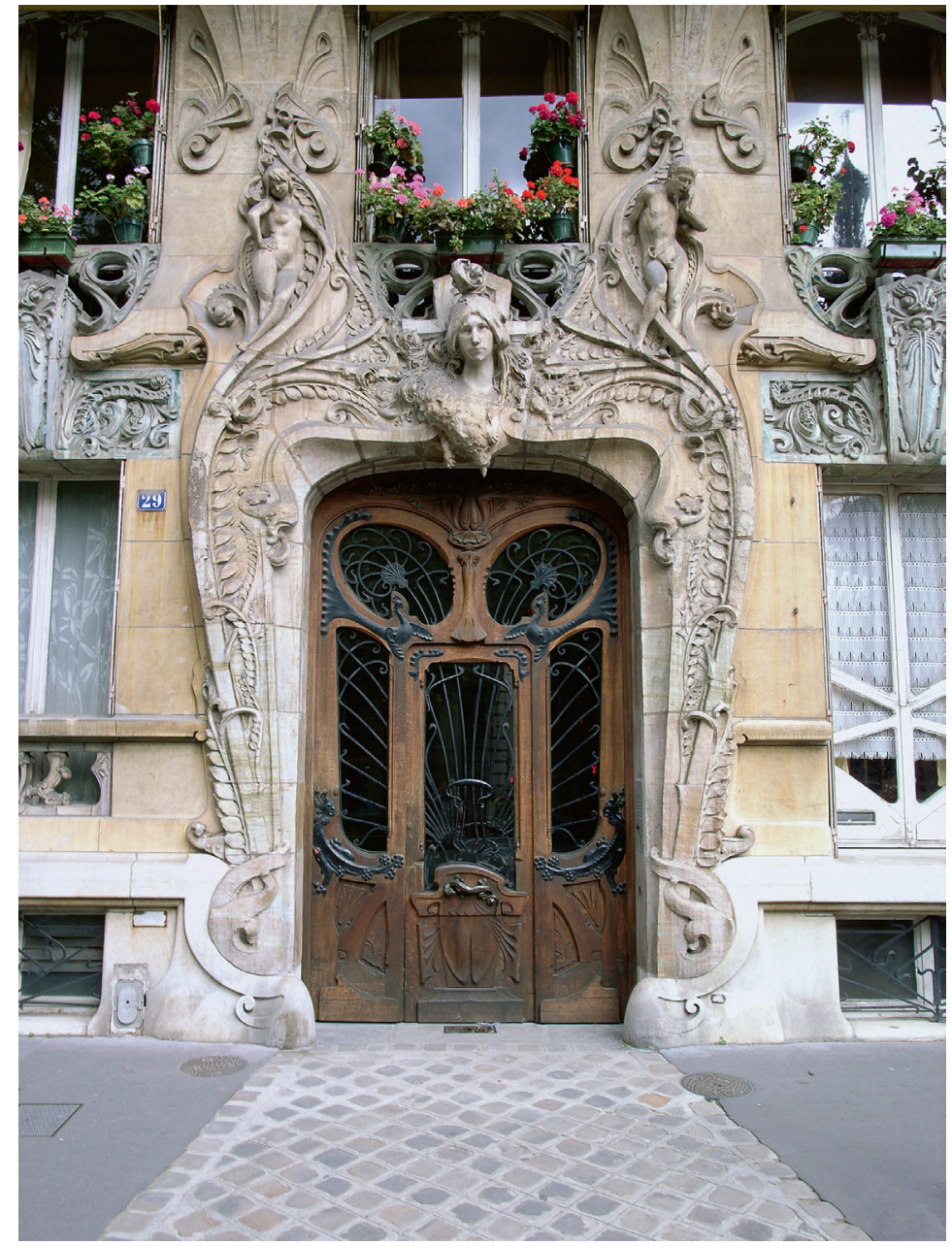

rivers or seas. ${ }^{48}$ For example, the geographer Yakut al-Hamawi (574-626/1179-1229) observed that: "the porticoes of the mosque contain every city and every kind of tree in the world."49 In other words, the medieval viewers viewed this iconography as a synthetized reflection of the human life's domain with its two constitutive elements, the natural and the built environment. But more conspicuous in these sources is the praising of the mosaics' striking perceptual appearances and beauty that made the mosque a world marvel in the Medieval Muslim imaginary. This praise by the geographer Muhammad al-Idrisi, who visited the mosque in $548 / 1154$, is only one among many raving reports: "In Damascus there is a mosque that has no equal in the world, neither one with such fine proportions, nor one so solidly constructed, vaulted so securely, more marvellously laid out, or so admirably decorated in gold mosaics and diverse designs, with enamelled tiles and polished marbles." 50 Other, more pragmatic chroniclers underscore or even discuss the mosaics' sheer costs. It must be noted that no further evidence about this art can be extracted from the documentation on the Mosque of the Prophet in Medina and the Dome of the Rock that originally presented a mosaic programme similar to the Damascene decoration.

Based on this evidence, scholars offer three main lines of interpretation. The first line expectedly posits the mosaics as symbols of political-religious power and empire. The second line attributes to them eschatological and cosmological meanings, based on the Quran in which the numerous descriptions of Paradise can be analogically associated with the mosque's iconographic spectacle: 
But give glad tidings to those who believe and work righteousness, that their portion is gardens, beneath which rivers flow.

Q 2:25

Allah hath promised to Believers, men and women, gardens under which rivers flow, to dwell therein, and beautiful mansions in gardens of everlasting bliss.

Q 9:72

The third line endorses the two previous views in arguing that the mosaics constitute a multi-layered representation conveying both heavenly and earthly significations. However, none of these views is satisfactory. The first overarching symbolic political reading is hardly explanatory as it does not address the fundamental question of the mosaics' aesthetic ontology and workings. The second view comes up against the non-trivial problem of the medieval chroniclers' silence about alleged paradisal representations or connotations. Considering that these chroniclers did not refrain from describing the mosque, this silence plainly invalidates such a view. It indeed seems to me unfathomable that they would have ignored it, had the landscape-architecture imageries been specifically conceptualized as eschatological projections by whatever referential means, representation, symbolization, or connotation. Besides, the texts' terminology of cities, villages and castles is more evocative of earthly life than the ethereal heavenly afterlife. As for the third interpretation, it conveniently passes over the shortcomings of the two other views.

Apart from these flaws, all three readings fail on two crucial points. First, they unquestionably presuppose that, like their pre-Islamic models, the Umayyad mosaics operate according to referential modalities. If this presupposition partly stems from the legitimate inconceivability of a characterization of these mosaics as pure décor, nonetheless this inconceivability does not automatically validate this presupposition. Indeed, there remains the third hermeneutic possibility that these Umayyad masterpieces do not signify anything, while nevertheless assuming a function beyond mere embellishment. Despite the pitfalls of the representational logic, scholars did not consider this possibility, because they still abide by the pre-Modernist rule according to which any artwork, in the dignified sense of the word, by definition signifies something. Yet, twentiethcentury aesthetics and art like, say, Fernand Legér's "Contraste de Formes," have taught us that high artistic creation is not bound to signification. In failing to envisage this interpretive option, if only in the form of a question, scholars brought the hermeneutics of the Umayyad golden mosaics to a deadlock.

Second, the three readings ignore or did not take into account the measure of the eminently significant gesture of omission of the customary informative inscriptions and other identifying features found in the Byzantine models, such as recognizable topographies and localizable architectural shapes. ${ }^{51}$ The Umayyad landscape-architecture imagery has been emptied from even the most elementary linguistic indications, such as the word "palace," which one finds inscribed on the pediment of Theodoric's palace in the sixth-century mosaics of Sant' Apollinare Nuovo in Ravenna. Any potential discourse or residue of meaning embedded in the borrowed Late Antique iconography seems to have been effaced. Moreover, this absence of inscriptions contrasts with the presence of explanatory epigraphy within the iconography of other Umayyad monuments like Qusayr 'Amra. Given the centrality of writing in Umayyad visuality, this muting of the forms in the aesthetic context of a public building of the utmost religious-political importance can only signal a decisive intention. 


\subsection{A Gesture of Deterritorialization}

Undoubtedly of aporetic order, the conscious erasure of epigraphy and other informative features has the effect of eliminating any sense of history and belonging in the Umayyad golden mosaics, following a process I call “deterritorialization” by using Gilles Deleuze's concept: "that line of flight the signifying regime cannot tolerate, in other words, an absolute deterritorialization." 52 This process shapes this decoration's condition of meaning in an unprecedented manner that sharply differentiates the Umayyad religious visuality from the well mapped iconographic world of its Byzantine counterpart. Deleuzean "deterritorialization," the sound artist Will Schrimshaw explains, "is an unbinding of all that is fixed, a becoming flexible, mobile, a slippage in terms of identity, a movement beneath and beyond the signifier." 53 In visual art, this "beyond the signifier" resides in the works' aesthetic materialities themselves, deliberately laid bare in order to induce a phenomenology of pure sensory affect. Consequently, one may say that, in the mosque's iconography, deterritorialization provides a means of exit from representation and discourse and, by the same token, an access to the silent domain of non-symbolic ornament.

In the history of this field of studies however, not all scholars have overlooked this hermeneutic possibility of the mosaics' mute ornamental ontology. In an exceptional intellectual move, Oleg Grabar brought forth this idea of a discourse-free mosaic ornament in Umayyad religious architecture, as he made this momentous comment about the Dome of the Rock: "Much of its power as a work of art derives from the almost embarrassing beauty of its features and the absence of any immediately identifiable message. In this sense, it is a remarkably contemporary work of art which imposes itself by its forms more than by its meanings." 54 Made in the nineties, this mind-opening comment has remained unheeded until today, unsurprisingly given the studies' state of affairs just expounded. Instead, the scholarship took upon the task of undermining the very premises on which Grabar based his view, which consist of the demonstrable, if not always well-understood and ethnocentric ideology-free, conceptual-aesthetic connections between Western abstract art and Islamic ornament. Since the fifties indeed, a few scholars and curators have been trying to expose and explore these connections, against an increasingly reluctant scholarship deeming this approach anachronistic and neo-Orientalist. ${ }^{55}$ It is true though, that Grabar expressed his thought in the brut form of an intuition calling for further clarification and argument. Still, his mention of "a contemporary work of art" rightly implies that, long before Western Abstraction, the Umayyads had liberated the visual forms from the strictures of content. Let me now turn Grabar's brilliant intuition into an explanation.

\subsection{Tautologized Iconography and Nonmeaning}

In Grabar's thought, what actually links "the contemporary art work" to the Umayyad mute mosaics of Damascus, Jerusalem and Medina, is aporia or the suppression of the signified meaning in art, and the displacement of the aesthetic logic of sense in the beyond of signification and discourse. Not yet in possession of artistic formulas of their own, the Umayyads espoused the habit of their non-Muslim predecessors whose most prestigious religious edifices impacted the governed communities' consciousness with awe-inspiring iconographic spectacles. However, the Umayyad envisioning of such spectacles for their own places of worship was not similarly underpinned by an illustrative-narrative project, because the Islamic-Umayyad means of thought communication in the visual realm was not the image, as we may recall, but writing. The golden landscapes-cityscapes, as well as the vases and the jewels, reflect this de-possession of the image's traditional communicative mission. How then to apprehend these asignifying Umayyad imageries? 
While the mosaic iconographies' perceptual assets appear fully exploited, their representational-discursive properties reduce themselves to a tautological selfpresentation: "the tree in the spandrel is a tree in the spandrel," "the house above the river is a house above a river," etc. They consequently must be seen the same way as Donald Judd looked at Jackson Pollock's paintings as he wrote, "the dripped paint ... is dripped paint ... It's not something else that alludes to dripped paint." ${ }^{\prime 6}$ If, in their descriptions, the medieval chroniclers naturally used a less straightforward critical terminology than Judd, they nonetheless spoke an analogous quasi-tautological language. Calling a cluster of edifices a village, a city, or a castle, or a body of water a sea, an ocean, or a river, does not change the principle at stake.

By thus emptying iconography from any meaning beyond the tautological enunciation in their religious buildings, the Umayyads brought representation itself close to death. For if the silent imageries signify something tangible, it is the reprieve that this incomplete eradication of visual discourse, or ultra-reduction of it in the tautology gives to representation before its progressive, albeit ineluctable eradication in post-Umayyad religious architecture. ${ }^{57}$ This reprieve, however, does not prevent the imageries' structural power from transfiguring them into mute ornaments, and thereby from placing their objective-material phenomenology at the heart of the aesthetic experience. With their insistent commentaries on the awesome beauty and costs of the mosque's decoration, showing more interest in its material qualities than in its iconography, the primary sources strongly support this phenomenological analysis. Unconceivable indeed as pure décor in this architectural-aesthetic context conceptualized as material applications (not representations) of Islamic spiritual ideals, the Umayyad golden mosaics are, by inference, sites of nonmeaning.

This interpretation raises two questions. Do these mosaics allow for the potential constitution of meaning, or do they form instead full-fledged a-referential pure materialities analogous to the Minimalist artists' hyper-concrete works? Once again, my answer accommodates the two ideas. Although the colourful iconography cannot completely block the generation of some form of meaning and obviously constitutes a powerful stimulus for the imaging imagination, the forms' radical ornamentalization activates the forces of a phenomenology of concrete materiality akin to that of Minimalist works. This phenomenology definitely posits the mosaics as structures operating in the region of objecthood. However, the ultra-narrow representational space of the iconographic tautology forms fissures in the structures through which meaning may emerge; and here lies the difference between these and the "total structures," as I would call them, of the post-Umayyad geometric Islamic ornaments.

In the state of a potentiality instead of a reality, this (non)meaning does not reside in and is not given by the forms themselves. To be actualized, it requires the action of an external agent, namely the viewers. In a Wittgensteinian projective manner, the latter may establish associations and build metaphors based on the landscape-architecture imagery's tautology. In this process called "participation" in the idiom of contemporary art criticism, the mind constitutes both the creator and locus of this meaning in virtual becoming. ${ }^{58}$ Actually, the villages, cities, oceans, and other generic mundane entities mentioned in the sources are in a certain way the product of this participatory process, if only through the use of a vernacular imaging language. Similarly, the scholars' paradisal visions and other perceived representations and connotations are participatory subjective responses to the art, not scholarly explanations of it..$^{59}$ That is true at least if one looks at the Umayyad visual forms thus redefined in participatory, aporetic, and ornamental terms. 
Their aporetic manipulations of the pre-Islamic visual languages yielded the Umayyads to create an ornamental aesthetic equivalent, in twentieth-century Western literature, to the "style of absence which is almost an ideal absence of style," which Roland Barthes detected in Albert Camus and Maurice Blanchot's non-rhetorical literary expression. ${ }^{60}$ This "style of absence," or the aporia fashioning the Umayyad tautological golden mosaics, favours, again to paraphrase Barthes, "a neutral and inert state of form; thus thought remains wholly responsible, without being overlaid by a secondary commitment of form to a history not its own." ${ }^{11}$ In the Umayyad context, the ornamentalization and deterritorialization of the borrowed forms de-historicize them, in order to build a nondiscursive aesthetic space allowing the viewers' thought and feelings to remain "wholly responsible" in the elaboration of the art's meaning, in other words, to participate. It is my contention that in such an ornamental environment, a "felt space" as Gernot Böhme would define it, an intimate and precepts-free relationship with God may genuinely construct itself. ${ }^{62}$ While calligraphy assumes the art's didactic-discursive function, the ornamentalized materialities allow for a purely immersive aesthetic experience through which pure divine love rises in the faithful's heart and exerts on them all its affective might. For in Islam, what I call "the affective understanding" pertains to the divine obligations, alongside conscious obedience, and belief.

\section{About the Author}

Valérie Gonzalez is Research Associate at soAs, University of London.

She is a specialist of Islamic art history, aesthetics, and visual culture. She obtained a $\mathrm{PhD}$ in Islamic Studies, University of Provence Aix-Marseille, and a Master of Fine Arts, School of Fine Arts, Marseille-Luminy. Her research addresses fundamental conceptual issues and creative processes in the Islamic artistic practices past and present, such as figurality, abstraction, pictorial metaphysics, or the philosophy of ornament. Her work relies on an interdisciplinary methodology ranging from art criticism and theory, aesthetic phenomenology, and philosophy to linguistics, as well as the comparison with other global arts. She also writes critical texts for contemporary artists of Muslim heritage and/or interested in Islamic aesthetics.

She was awarded scholarships from institutions such as the Kunsthistorisches Institut-Max-Planck-Institut, Florence, The Getty Research Institute, the Aga Khan Program for Islamic Architecture in MIT, and the Institute for Advanced Study, Princeton.

Her books include: Aesthetic Hybridity in Mughal Painting, 1526-1658, Ashgate 2015; Le piège de Salomon, La pensée de l'art dans le Coran, Albin Michel, 2002, and Beauty and Islam, Aesthetics of Islamic Art and Architecture, I.B. Tauris, 2001.

In 2004, her article "The Comares Hall in the Alhambra and James Turrell's Space that Sees: A comparison of Aesthetic Phenomenology," (Muqarnas, 20) won the Eisenstein Prize.

\section{Bibliography}

Ali, Nadia (2017). The royal veil: early Islamic figural art and the Bilderverbot reconsidered. Religion 47 (3), pp. 425-44. 
Allen, Terry (1988). Aniconism and Figural Representation in Islamic Art. In: Five Essays in Islamic Art, Sebastopol, CA: Solipsist Press, pp. 17-37.

Almond, Ian (2004). Sufism and Deconstruction, A Comparative Study of Derrida and Ibn 'Arabi. London, New York: Routledge.

Altieri, Charles (2003). The Particulars of Rapture: An Aesthetics of the Affects.

Arkoun, Mohammed (200o). Present Day Islam between Its Tradition and Globalization. In: Farhad Daftary, ed., Intellectual Tradition in Islam, London: I. B. Tauris/Institute of Ismaili Studies, pp. 179-221.

Barthes, Roland (1970). Writing Degree Zero. Translated by Annette Lavers and Colin Smith. Boston: Beacon Press Books.

Bishop, Claire, ed. (2009). Participation, Documents of Contemporary Art. London: Whitechapel Gallery, Cambridge, MA: Miт Press.

Böhme, Gernot (2017). Atmospheric Architectures, The Aesthetic of Felt Spaces. London: Bloomsbury Academic.

Bourriaud, Nicolas (1998). Relational Aesthetics. Dijon: Les Presses du Réel.

Brennan, Teresa (2004). The Transmission of Affect. Ithaca: Cornell University Press.

Burns, Ross (2005). Damascus: A History. London, New York: Routledge.

Clarke, John R. (2006). Art in the Lives of Ordinary Romans, Visual Representation and Non-Elite Viewers in Italy. Oakland: University of California Press.

Cumplido, Nieto (2005). La Mezquita Catedral de Córdoba. Patrimonio de la Humanidad. Granada: Edilux.

Ćurčić, Slobodan (2011). Aesthetic Shifts in Late Antique Art: Abstraction, Dematerialization, and Two-Dimensionality. In: Anastasia Lazaridou, ed., Art of Late Antiquity, 3rd-7th Century $A D$, New York: Onassis Foundation, pp. 67-73.

Dabashi, Hamid (200o). In: the Absence of the Face. Social Research 67 (1), pp. 127-85.

Deleuze, Gilles and Guattari, Felix (2013). A Thousand Plateaus, Capitalism and Schizophrenia. Translated by Brian Massumi. London, New Delhi, New York, Sydney: Bloomsbury Academic.

Derrida, Jacques (1978). Writing and Difference, translated by Alan Bass. Chicago: The University of Chicago Press.

Dietrich, Nikolaus and Squire, Michael, eds. (2018). Ornament and Figure in Graeco-Roman Art. Berlin, Boston: De Gruyter.

Eisenlohr, Patrick (2018). Sounding Islam, Voice, Media and Sonic Atmospheres in an Indian Ocean World. Oakland: University of California Press.

Elias, Jamal J. (2012). Aisha's Cushion, Religious Art, Perception and Practice in Islam. Cambridge, MA: Harvard University Press.

Elsner, Jas (2004). Late Antique Art: The Problem of the Concept and the Cumulative Aesthetic. In: Simon Swain and Mark Edwards, eds., Approaching Late Antiquity: The Transformation from Early to Late Empire, Oxford: Oxford University Press, pp. 271-309.

Flood, Finbarr B. (2009). Objects of Translation: Material Culture and Medieval 'Hindu-Muslim' Encounter. Princeton: Princeton University Press.

Flood (2016). Animal, Vegetal, and Mineral: Ambiguity and Efficacy in the Nishapur Wall Paintings. Representations 133 (1), pp. 20-58.

Flood (2018). Bodies, Books, and Buildings, Economies of ornament in juridical Islam. In: David Ganz and Barbara Schellewald, eds., Clothing Sacred Scriptures: Book Art and Book Religion in Christian, Islamic, and Jewish Cultures, Berlin: Gruyter, pp. 49-68.

Flood (2016-7) and (2018). Picasso the Muslim, or how the Bildeverbot Became Modern (Part 1) and (Part 2). Res: Anthropology and Aesthetics, 67-8, pp. 42-6o, and 69-70, pp. 251-268.

Flood (1997). Umayyad Survivals and Mameluk Revivals: Qalawunid Architecture and the Great Mosque of Damascus. Muqarnas 14, pp. 57-79. 
Flood (2001). The Great Mosque of Damascus, Studies on the Making of an Umayyad Visual Culture. Leiden: Brill.

George, Alain (2017). Paradise or Empire, On a Paradox on Umayyad Art. In: Alain George and Andrew Marsham, eds., Power, Patronage and Memory in Early Islam: Perspective on Umayyad Elite, Oxford: Oxford University Press, pp. 39-67.

Gonzalez, Valerie (2015). Epistemological Preliminaries. In: Aesthetic Hybridity in Mughal Painting, 1526-1658, Aldershot: Ashgate.

Gonzalez (2003). The Comares Hall in the Alhambra and James Turrell's Space that Sees: A comparison of Aesthetic Phenomenology. Muqarnas 20, pp. 253-278.

Gonzalez (2018). The Hermeneutics of Islamic Ornament: The Example of the Alhambra. In: Sabine Schmidtke, ed., Studying the Near and Middle East at the Institute of Advanced Study, Princeton, 1935-2018. Piscataway, NJ: Gorgias Press, pp. 375-88.

Grabar, Oleg (1992). The Mediation of Ornament. Princeton: Princeton University Press.

Grabar (1996). The Shape of the Holy, Islamic Jerusalem. Princeton: Princeton University Press.

Grafman, Rafi and Rosen-Ayalon, Myriam (1999). The Two Great Syrian Umayyad Mosques: Jerusalem and Damascus. Muqarnas 16, pp. 1-15.

Graves, Margaret (2019). Arts of Allusion, Object, Ornament, and Architecture. Oxford: Oxford University Press.

Ha'iri Yazdi, Mehdi (2017). Universal Science: An Introduction to Islamic Metaphysics. Leiden: Brill. Hegel, Georg Wilhelm Friedrich (1975). Aesthetics: Lectures on Fine Art, translated by T.M. Knox (2 vols.). Oxford: Clarendon.

Hillenbrand, Robert (2012). Reflections on the Mosaics of the Umayyad Mosque in Damascus. In: Arabia, Greece and Byzantium, Cultural Contacts in Ancient and Medieval Times. Riyadh: King Fahad National Library Publications, pp. 163-187.

Jones, Tamsin (2016). New Materialism and the Study of Religion. In: Joerg Rieger and Edward Waggoner, eds., Religious Experience and New Materialism: Movement Matters, London: Palgrave, Macmillan, pp. 1-23.

Judd, Donald (1965). Specific Objects. In: Contemporary Sculpture: Arts Yearbook 8. New York: Art Digest, pp. 74-82.

Judd (1975). Donald Judd: Complete Writings 1959-1975, Gallery Reviews, Book Reviews, Articles, Letters to the Editor, Reports, Statements, Complaints. Halifax and New York: The Press of the Nova Scotia College of Art and Design.

Kazemi, Reza-Shah (2003). Divine Beatitude: Supreme Archetype of Aesthetic Experience. In: Barry McDonald, ed., Seeing God Everywhere, Essays on Nature and the Sacred, Bloomington, IN: World Wisdom, pp. 215-26.

Khalil, Usman and Khan, Abida (2013). Islam and Postmodernity: M. Arkoun on Deconstruction. Journal of Islamic Thought and Civilization, Vol. 3 (1) online:http://admin.umt.edu.pk/Media/ Site/UMT/SubSites/jitc/FileManager/JITC\%2oSpring\%202013/2.\%2oIslam\%2oand\%2O Postmodernity.pdf.

Logocentrism. The Chicago School of Media Theory, 29, online: https://lucian.uchicago.edu/ blogs/mediatheory/keywords/logocentrism/.

Marenk, Betti and Brassett, Jamie eds. (2015). Deleuze and Design. Edinburgh: Edinburgh University Press.

Marks, Laura U. (2010). Enfoldment and Infinity: An Islamic Genealogy of New Media Art. Cambridge, MA: Mit Press.

Massey, Jonathan (2013). Ornament and Decoration. In: Graeme Brooker and Lois Weinthal, eds., The Handbook of Interior Architecture and Design, London, New Delhi, New York, Sydney: Bloomsbury, pp. 497-513.

Melvin-Koushki, Matthew (2016). Of Islamic Grammatology: Ibn Turka's Metaphysics of Light. Al-'Ușūr al-Wusțā 24, pp. 42-113. 
Merleau-Ponty, Maurice (1964). Signs. Translated by Richard C. McClearly. Evanston: Northwestern University Press.

Meyer, Birgit, ed. (2009). Aesthetic Formations, Media, Religion, and the Senses. New York: Palgrave Macmillan.

Moran, Dermott (2011). Gadamer and Husserl on Horizon, Intersubjectivity, and the Life-world. In: Andrzej Wiercinski, ed., Gadamer's Hermeneutics and the Art of Conversation, International Studies in Hermeneutics and Phenomenology (2 Vols.), Münster: Lit Verlag, Volume 2, pp. 73-94.

Morgan, David (2010). The Material of Lived Religion: Visuality and Embodiment. In: Johanna Vakkari, ed., Mind and Matter: Selected Papers of the Nordik 2009 Conference for Art Historians, Helsinki: Helsingfors, pp. 14-31.

Natif, Mika (2011). The Painter's Breath and Concepts of Idol Anxiety in Islamic Art. In: Idol Anxiety. Josh Ellenbogen and Aaron Tugendhaft, eds., Stanford, CA: Stanford University Press, pp. 41-55.

Necipoğlu, Gülru (1995). The Topkapi Scroll. Geometry and Ornament in Islamic Architecture. Los Angeles: J.P. Getty Center Publications.

Necipoğlu (2007). Lidée de décor dans les régimes de visualité islamiques. In: Remi Labrusse, ed., Purs Décors? Arts de l'Islam, regards du XIX siècle: Collections des Arts Décoratifs, Paris: Musée du Louvre, pp. 10-23.

Necipoğlu (2016). Early Modern Floral: The Agency of Ornament in Ottoman and Safavid Visual Cultures. In: Gülru Necipoğlu and Alina Payne, eds., Histories of Ornament, Ornament: From Global to Local, Princeton: Princeton University Press, pp. 132-55.

O'Hagan, Sean (2018). Interview, Stephen Rea, "No matter how much they enforce Brexit, British Identity is dwindling", The Guardian. Sunday 3 o September.

O'Meara, Simon (2020). The Kacba Orientations, Readings in Islam's Ancient House. Edinburgh: Edinburgh University Press.

O’Meara (2019). Haptic Vision: Making Surface Sense of Islamic Material Culture. In: Robin Skeates and Jo Day, eds. The Routledge Handbook of Sensory Archaeology, London, New York: Routledge, pp. 467-80.

Pancaroğlu, Oya (2017). Figural Ornament in Medieval Islamic Art. In: Finbarr B. Flood and Gülru Necipoğlu, eds., A Companion to Islamic Art and Architecture, (2 Vols.), Hoboken, NJ, Oxford: Wiley Blackwell, Volume 2, pp. 501-520.

Pericolo, Lorenzo and Nagel, Alexander, eds. (2010). Subject as Aporia in Modern Art. Aldershot: Ashgate.

Piccirillo, Michele Fr. (1993). Mosaics of Jordan. Amman, Jordan: American Center of Oriental Research.

Puerta Vílchez, José Miguel (2015). El sentido artístico de Qurtuba / The Artistic Sense of Qurtuba. Granada: Edilux-Casa Árabe.

Rabbat, Nasser (1989). The Meaning of the Umayyad Dome of the Rock. Muqarnas 6, pp. 12-21.

Rabbat, Nasser (1997). The Mosaics of the Qubba al-Zahiriyya in Damascus: A Classical Syrian Medium Acquires a Mamluk Signature. Aram Periodical, pp. 1-14.

Rancière, Jacques (2013). The Politics of Aesthetics. Translated by Gabriel Rockhill, London, New Delhi, New York, Sydney: Bloomsbury Academic.

Rizvi, Kishwar, ed. (2017). Affect, Emotion, and Subjectivity in Early Modern Muslim Empires: New Studies in Ottoman, Safavid, and Mughal Art and Culture. Leiden: Brill.

Rubiera Mata, María Jesús (1988). La arquitectura en la literatura Árabe, datos para una estética del placer. Madrid: Hiperión.

Schrimshaw, Will (2019). Immanence and Immersion, On the Acoustic Condition in Contemporary Art. New York, London: Bloomsbury Academic. 
Shalem, Avinoam and Troelenberg, Eva-Maria (2010). Au-delà de la grammaire et de la taxinomie: l'expérience cognitive et la responsivité de l'ornement dans les arts de l'Islam. Perspective 1, pp. $57-76$.

Shukurov, Sharif (2009). Review Essay: Art History as a Theory of Art. Ars Orientalis 36, pp. $215^{-3} 6$.

Soucek, Priscilla (1993). Solomon's Bath/Solomon's Throne: Model or Metaphor? Ars Orientalis Vol. 23, pp. 109-34.

Squire, Michael (2018). To Haunt, to startle, and way-lay: Approaching ornament and figure in Graeco-Roman art. In: Dietrich, Nikolaus and Squire, Michael, eds., Ornament and Figure in Graeco-Roman Art. Berlin, Boston: De Gruyter, pp. 1-35.

Stanford Encyclopedia of Philosophy https://plato.stanford.edu.

Stordalen, Terje (2016). Imagining Solomon's Temple: Aesthetics of the Non-Representable. In: Birgit Meyer and Terje Stordalen eds., Figurations and Sensations of the Unseen in Judaism, Christianity and Islam: Contested Desires, London: Bloomsbury Academic, pp. 21-36.

Suleman, Fahmida, ed. (2003). Word of God, Art of Man, The Qur'an and its Creative Expression. Oxford: Oxford University Press, London: The Institute of Ismaili Studies.

Taminiaux, Jacques and Crease, Robert (1980). Merleau-Ponty, From Dialectic to Hyperdialectic. Research in Phenomenology, Vol. 10, pp. 58-76.

Taragan, Hana (2019). Textiles in Cross-Cultural Encounters: The Case of the Umayyad Palace at Khirbat al-Mafjar. Al-Masāq Vol. 31, pp. 140-55.

Walker, Alicia (2008). Cross-cultural Reception in the Absence of Texts:TheIslamic Appropriation of a Middle Byzantine Rosette Casket. Gesta 47 (2), pp. 99-122.

\section{Notes}

1 I call this twentieth and twenty-first century philosophy "contemporary." About this artist, see these websites: https://www.timothytaylor.com/artists/shezad-dawood/; https://www.saatchigallery.com/ artists/shezad_dawood.htm.

2 See, for example, Ian Almond (2004). Sufism and Deconstruction, A Comparative Study of Derrida and Ibn Arabi. London, New York: Routledge; Matthew Melvin-Koushki (2016). Of Islamic Grammatology: Ibn Turka's Metaphysics of Light. Al-'Ușūr al-Wusțā 24, pp. 42-113; and Patrick Eisenlohr (2018). Sounding Islam, Voice, Media and Sonic Atmospheres in an Indian Ocean World. Oakland: University of California Press.

3 Ian Almond (2004), 2.

4 David Morgan (2010). The Material of Lived Religion: Visuality and Embodiment. In: Johanna Vakkari, ed., Mind and Matter: Selected Papers of the Nordik 2009 Conference for Art Historians, Helsinki: Helsingfors, pp. 14-31. See also, among a wealth of publications, Tamsin Jones (2016). New Materialism and the Study of Religion. In: Joerg Rieger and Edward Waggoner, eds, Religious Experience and New Materialism: Movement Matters, London: Palgrave, Macmillan, pp. 1-23; and Birgit Meyer ed. (2009). Aesthetic Formations, Media, Religion, and the Senses. New York: Palgrave Macmillan.

5 Pioneer in the investigation of primary aesthetics for the study of Islamic art is Gülru Necipoğlu (1995). The Topkapi Scroll. Geometry and Ornament in Islamic Architecture. Los Angeles: J.P. Getty Center Publications. On the basis of this aesthetics, Necipoğlu cogently demonstrates the anagogical property of the pre-Modern geometric designs, thereby ruling out the Orientalist reading of these designs as pure décor. However, this seminal book also shows the Islamic primary aesthetics' critical limitations. Although the period texts allow for the understanding of the art's intellectual context and the system of aesthetic values it conveys, they seldom enlighten the artworks and the artistic practice and experience themselves.

6 The online Stanford Encyclopedia of Philosophy https://plato.stanford.edu is an excellent resource for getting acquainted with all kinds of philosophy and many thinkers past and present.

7 Leading this salutary current of Islamic art history is Finbarr B. Flood (2009). Objects of Translation: Material Culture and Medieval 'Hindu-Muslim' Encounter. Princeton: Princeton University Press. About this problem affecting the critical inquiry, see my thorough critique in Valerie Gonzalez (2015). Epistemological Preliminaries. In: Aesthetic Hybridity in Mughal Painting, 1526-1658, Aldershot: Ashgate, pp. $1-63$. 
8 Finbarr B. Flood being also involved in this change, his writings deserve attention. For example, in Flood (2016). Animal, Vegetal, and Mineral: Ambiguity and Efficacy in the Nishapur Wall Paintings. Representations 133 (1), pp. 20-58, the scholar's genealogy of the Nishapuri paintings confirms the established evidence that they constitute a local version of the ninth and tenth-centuries transregional Islamic ornamental language. Yet, based on the presence of hand and eye-like forms and the stylistic plays with abstraction and figuration, Flood proposes a "presentational-representational" re-reading of these paintings as ambiguous or unstable apotropaic images. His theoretical discussion on apotropaic efficacy, replete with talismanic instances in various cultural contexts, builds an informative historical and anthropological background to his hypothesis, but it does not support it critically. For this theory of efficacy has little bearing on this specific painted ensemble as primarily an ornamental structure. The oscillation between abstraction and figuration, common in ornamental constructs in general and in Islam in this period, suspends meaning by sublation (a dialectical process, see the subsequent theoretical expose), therefore it cannot be advanced as a supporting argument for a representational/presentational interpretation. As for the possible apotropaic images-symbols, they are by definition neither representational nor presentational. This type of motif affects the designs in which it appears, by lending them apotropaic properties. All in all, these paintings are stable ornamental structures possibly imbued with such properties. Consequently, the chief problem the essay eludes because of the representational view it endeavours to argue, is the actual degree of efficacy of these properties, if not the lack of thereof in the sublative ornamental context of the Nishapuri architectural site.

9 This is observable in Finbarr B. Flood (2018). Bodies, Books, and Buildings, Economies of ornament in juridical Islam. In: David Ganz and Barbara Schellewald, eds., Clothing Sacred Scriptures: Book Art and Book Religion in Christian, Islamic, and Jewish Cultures, Berlin: Gruyter, pp. 49-68. The few references to Western thinkers underscore certain points of the article, but they do not contribute much to its substance as a compilation of the well-known texts forming the Islamic proscriptive discourse on ornament and precious metals. On the other hand, this compilation mentions, but does not discuss the fundamental issue of the discrepancies between this discourse and the ornamental practices. This issue is rendered even more elusive through the blunt statement about "the widespread perception of Islamic art as an art of ornament" (p. 66), echoing another similar assertion about Islamic art being "perceived" as abstract, repeated throughout Flood's two-part article (2016-7) and (2018), Picasso the Muslim, or how the Bildeverbot Became Modern (Part 1) and (Part 2). Res: Anthropology and Aesthetics, 67-8, pp. 42-6o, and 69-70, pp. 251-68. From a critical viewpoint, these essays ultimately deliver an impressionistic view of Islamic art as "not so abstract and not so ornamental" seeping through the historical data.

10 The misapprehension of abstraction and figuration in Necipoğlu (1995) is a case in point. She purports that the mental images generated by the geometric forms facilitate higher abstract thoughts because they are less dependent on sensory perception than figurative representations (p. 210). However, either mentally constructed or recognized as already formed in the artwork's materiality, both types of image are seen/perceived by the viewer in this materiality by means of the material signals embedded in it. As images are not real things and constitute themselves through the external referents represented in them, be they figurations or else, to exist they require in equal measure the physical perception of these signals. Magritte's famous picture Ceci n'est pas une pipe plays with this image ontology. For this very reason, a Velasquez or a Giotto painting provokes as much higher abstract thoughts as Islamic geometric designs. The difference between them resides in the mode of constitution of the images' referents, which give access to such thoughts. In figurative representation, the signals project ready-made referents forming a recognisable image, whereas in geometric abstraction, they only suggest potential referents based on which viewers mentally may construct an image of their own. Consequently, exactly like for figurative representation, Islamic geometric design must be pondered based on its material agency, not despite or beyond it.

11 These confusions underpin in particular Margaret Graves (2019). Arts of Allusion, Object, Ornament, and Architecture. Oxford: Oxford University Press; and Oya Pancaroğlu (2017). Figural Ornament in Medieval Islamic Art. In: Finbarr B. Flood and Gülru Necipoğlu, eds., A Companion to Islamic Art and Architecture, (2 Vols.), Hoboken, NJ, Oxford: Wiley Blackwell, Volume 2, pp. 501-20. In Graves' book, in the chapter "Building Ornament," the author cumbersomely explains what can be described in a sentence with a precise aesthetic term: "a transduction" of architectural vocabulary in the portable objects' formal registers. Graves puts both the ornamental and non-ornamental forms thus transductively produced in the same category of ornament, thereby dissolving the concept's specificities. Indeed, the said transduction may variably transform the object into an architectural miniature analogous to an autonomous sculpture, representational or generic, or/and into a medium 
of architectural iconography, with or without figurations, whose surfaces become the equivalent of a canvas or a wall. This iconography can be representational or ornamental if its referential power remains at the generic level. For example, the image of a niche with a lamp is a representation of the Quranic textual icon of divine light, and an arcade evoking a (any) mosque's portico an ornament. The aesthetic and cognitive stakes are considerably different in these two cases. Whereas the archetypal arcade may indifferently adorn a wide range of objects, astrolabes, incense burners or fabrics, the Quranic lamp image appears only on specifically chosen media such as tomb stones, mihrabs, or prayer rugs, for specific discursive or referential purposes.

12 Nikolaus Dietrich, and Michael Squire, eds. (2018). Ornament and Figure in Graeco-Roman Art. Berlin, Boston: De Gruyter.

13 Michael Squire (2018). To Haunt, to startle, and way-lay: Approaching ornament and figure in Graeco-Roman art. In: Ibid., pp. 2 and 22. See in particular his detailed analysis of the "Euphorbus Plate" (British Museum), pp. $3^{-16 .}$

14 Jonathan Massey (2013). Ornament and Decoration. In: Graeme Brooker and Lois Weinthal eds., The Handbook of Interior Architecture and Design, London, New Delhi, New York, Sydney: Bloomsbury, p. 498.

15 See Terry Allen (1988). Aniconism and Figural Representation in Islamic Art. In: Five Essays in Islamic Art, Sebastopol, CA: Solipsist Press, pp. 17-37; Oleg Grabar (1992). The Mediation of Ornament. Princeton: Princeton University Press; and Sharif Shukurov (2009). Review Essay: Art History as a Theory of Art. Ars Orientalis 36, pp. 215-36. For Western medieval and Byzantine ornament, see the rich bibliography in Alicia Walker (2008). Cross-cultural Reception in the Absence of Texts: The Islamic Appropriation of a Middle Byzantine Rosette Casket. Gesta 47 (2), pp. 99-122. I thank Anna Contadini for bringing this article to my attention.

16 In Avinoam Shalem and Eva-Maria Troelenberg (2010). Au-delà de la grammaire et de la taxinomie : l'expérience cognitive et la responsivité de l'ornement dans les arts de l'Islam. Perspective 1, pp. 59-6o, the authors add Rudolf Arnheim's theories of perception and forms to canonical references such as Ernst Gombrich's theory of "the sense of order." However, their use of these theories does not go beyond obvious generalizations such as "la capacité de ce phénomène visuel à susciter une réaction" (my translation: "the capacity of this visual phenomenon [ornament] to provoke a reaction") or the observation that ornament is not necessarily devoid of iconography. (p. 58) Moreover, in the title, the enunciation "the responsivity of ornament" is conceptually incorrect: ornament cannot perceive therefore it cannot be responsive. Perhaps the authors meant to say "the viewer's responsivity to ornament."

17 Shukurov (2009), p. 231. Some clarification is needed about this point in Shalem and Troelenberg (2010). To assert their view of Islamic ornament as a discursive device analogous to iconography, the authors mention a 2009 exhibition in Vienna in which Middle Eastern contemporary artists presented works involving ornament for the purpose of expressing contemporary concerns such as war, gender, freedom etc. (p. 57) https://www.youtube.com/watch?v=oolnTAuOFxs.Based. However, similarly to some aforementioned Graeco-Roman artworks, these contemporary pieces form complex constructs in which ornament is only an instrument to achieve goals beyond the ornamental itself, as many include multireferential devices and images. Gustav Klimt's paintings illustrate the methodological issue such an analysis raises. While ornament constitutes a prominent mute element in their compositions, these paintings nevertheless remain fundamentally representational. They play with the contrast between ornamental muteness and figural discourse. In sum, it is not a supposed discursivity of ornament that was at work in this exhibition, but both its signaletic ability to represent a given social body as a cultural code, like say, Palestinian embroidery, and its power to create dialectics when used in intersectionality with representational vocabularies.

18 Jacques Derrida (1978). Writing and Difference, translated by Alan Bass. Chicago: The University of Chicago Press, p. 5, and for further insights on the concept of structure, pp. $3^{-} 3^{\circ}$.

Derrida (1978), p. 5 .

See Charles Altieri (2003). The Particulars of Rapture: An Aesthetics of the Affects. Cornell University Press; Teresa Brennan (2004). The Transmission of Affect. Ithaca: Cornell University Press; Betti Marenk and Jamie Brassett, eds. (2015). Deleuze and Design. Edinburgh: Edinburgh University Press; Nicolas Bourriaud (1998). Relational Aesthetics. Dijon: Les Presses du Réel. To be clear, the phenomenological concept of affect theorized in these publications is not critically probed in the following book, despite its title: Kishwar Rizvi ed. (2017). Affect, Emotion, and Subjectivity in Early Modern Muslim Empires: New Studies in Ottoman, Safavid, and Mughal Art and Culture. Leiden: Brill. The press' blurb is astonishingly misconceived: "They [the contributors] consider the issue of affect as performative and responsive to certain emotions and actions, thus allowing insights into the motivations behind the making and, in some cases, the destruction of works of art ..." Affect cannot be "responsive to" certain emotions and actions, as it is the very agent that produces them. Again, the wording "the issue of affect ... as responsive to" makes no sense. It is the subject-viewer who is 
"responsive" to, i.e. affected by a certain affect, and acts accordingly. The book's actual content consists of conventional historical accounts of cultural events involving all kinds of human constructs, actions, and reactions such as piety, violence, politics, feelings, etc., put under the vulgarized term of "subjectivities" without any distinction between the conscious and the affective, and the felt and the thought.

21 Sharif Shukurov (2009) is therefore incorrect when he writes, "an ornament is not a sign of something, it does not indicate ...," p. 231. On the other hand, Terry Allen uses the appropriate albeit restrictive term of "emblematization," as emblems constitute only a specific kind of sign-form among others more conceptual in nature, in Allen (1988), pp. 17-37.

22 On signs, see Maurice Merleau-Ponty (1964). Signs. Translated by Richard C. McClearly. Evanston: Northwestern University Press; and https://plato.stanford.edu/entries/peirce-semiotics/\#Bib.

23 About the phenomenological concept of horizon, see Dermott Moran (2011). Gadamer and Husserl on Horizon, Intersubjectivity, and the Life-world. In: Andrzej Wiercinski, ed., Gadamer's Hermeneutics and the Art of Conversation, International Studies in Hermeneutics and Phenomenology (2 Vols.), Münster: Lit Verlag, Volume 2, pp. 73-94.

24 This chapel erected inside the Mosque-Cathedral of Cordoba is not to be confused with the Mudejar chapel dedicated to the same saint built outside the mosque. I am most grateful to José Miguel Puerta Vílchez for providing me with the images and documentation he and Nieto Cumplido gathered on this remarkable and little known aspect of Al-Hakam's refurbishment of the mosque. Their comparison of the paintings' iconography with ceramics of the period allowed them to discard the possibility of a Mudejar addition. See Nieto Cumplido (2005). La Mezquita Catedral de Córdoba. Patrimonio de la Humanidad. Granada: Edilux, pp. 104-105, and José Miguel Puerta Vílchez(2015). El sentido artístico de Qurtuba / The Artistic Sense of Qurtuba. Granada, Edilux- Casa Árabe, p. 34.

25 In Gülru Necipoğlu (2007). L'idée de décor dans les régimes de visualité islamiques. In: Remi Labrusse, ed., Purs Décors? Arts de l'Islam, regards du XIX ${ }^{e}$ siècle: Collections des Arts Décoratifs, Paris: Musée du Louvre, pp. 10-23, and in Necipoğlu (2016). Early Modern Floral: The Agency of Ornament in Ottoman and Safavid Visual Cultures. In: Gülru Necipoğlu and Alina Payne, eds., Histories of Ornament, Ornament: From Global to Local, Princeton: Princeton University Press, pp. 132-55, the scholar interprets the naturalistic plant depictions in Ottoman ornaments as a point of exit from both abstraction and the pre-Modern geometric art. However, this interpretation relies on the problematic conceptual collapsing of the forms' style and conceptualization. In fact, stylized or naturalistic, all the Ottoman floral motifs follow the same patterning rules of symmetry, modularity, and repetition ad infinitum inside geometric grids. These organizing features weaken the floral depictions' reference to nature and prevent it from disabling the flowery compositions' ornamental workings. Necipoğlu sees further evidence of a representational turn of early Modern ornament in the period sources and calligraphy evoking or comparing the Ottoman ornaments to gardens, including the Quranic paradise's garden. But such comparisons were standard in Islamic art since the Middle Ages, in diverse visual contexts. For example, in the Alhambra, calligraphies similarly compare muqarnas cupolas and different parts of the palace to gardens (see María Jesús Rubiera Mata (1988). La arquitectura en la literatura Árabe, datos para una estética del placer. Madrid: Hiperión, pp. 154-5).

26 In the rich literature on this art, see in particular Donald Judd (1965). Specific Objects. In: Contemporary Sculpture: Arts Yearbook 8. New York: Art Digest, pp. 74-82, and in Judd (1975). Donald Judd: Complete Writings 1959-1975, Gallery Reviews, Book Reviews, Articles, Letters to the Editor, Reports, Statements, Complaints, Halifax and New York: The Press of the Nova Scotia College of Art and Design, pp. 181-9.

27 In Finbarr B. Flood (2017-8), the author chronicles, in disparaging them, the comparative studies and museum displays that draw parallels between Islamic ornament and Western abstract art. The view of a transaesthetic connection beyond cultural-contextual differences is for Flood anachronistic, essentialist, and Eurocentric. For sure, the history of these comparative endeavours is not free of shortcomings and overreading. Yet, their premises remain valid and demonstrable, whereas the idea of enclosing Islamic art in a sealed cultural box with no transcultural ties and values appears, to me, ontologically reductionist and analytically unproductive. As examples of such comparative studies see, Laura U. Marks (2010). Enfoldment and Infinity: An Islamic Genealogy of New Media Art. Cambridge, MA: мiт Press; and Valerie Gonzalez (2003). The Comares Hall in the Alhambra and James Turrell's Space that Sees: A comparison of Aesthetic Phenomenology. Muqarnas 20, pp. $253^{-78 .}$

28 About nonmeaning and the related concepts of nondiscourse, silence and nonlanguage, see Derrida (1978), pp. 254-70.

29 In Hegelian thought, sublation, Aufheben or Aufhebung is a dialectical process leading to the cancellation or suspension of meaning, or to its reduction to a residue. Significantly, Hegel saw sublation at work in Chinese and Islamic art. See Georg Wilhelm Friedrich Hegel (1975). Aesthetics: Lectures on Fine Art, translated by T.M. Knox (2 vols.). Oxford: Clarendon; and https://plato.stanford.edu/ 
entries/hegel-aesthetics/\#HegTexLecAes. For Maurice Merleau-Ponty, the "hyperdialectic" describes the extreme form of an unsolved dialectic by which meaning is either lost or frozen. The dialectical process thus acquires a self-value allowing it to exempt itself from producing any result or meaning. See Jacques Taminiaux and Robert Crease (1980). Merleau-Ponty, From Dialectic to Hyperdialectic. Research in Phenomenology, Vol. 10, pp. 58-76.

The Latin term "aporia," from the Greek "aporos" (a/without-poros/passage) broadly signifies the blocking or blockage of meaning. See this case study: Lorenzo Pericolo and Alexander Nagel, eds. (2010). Subject as Aporia in Modern Art. Aldershot: Ashgate.

31 Sean O'Hagan (2018). "Interview, Stephen Rea, 'No matter how much they enforce Brexit, British Identity is dwindling', The Guardian. Sunday 30 September. https://www.theguardian.com/ stage/2018/sep/3o/stephen-rea-british-identity-is-dwindling-brexit-samuel-beckett-cyprus-avenue. See Mehdi Ha'iri Yazdi (2017). Universal Science: An Introduction to Islamic Metaphysics, Leiden: Brill. See Jamal J. Elias (2012). Aisha's Religious Art, Perception and Practice in Islam. Cambridge, MA: Harvard University Press; Mika Natif (2011). The Painter's Breath and Concepts of Idol Anxiety in Islamic Art. In: Idol Anxiety. Josh Ellenbogen and Aaron Tugendhaft, eds., Stanford, CA: Stanford University Press, pp. 41-55; and Allen (1988).

See Logocentrism. The Chicago School of Media Theory, 29, online: https://lucian.uchicago.edu/ blogs/mediatheory/keywords/logocentrism/.

35 For a deconstruction/reconstruction of Islamic logocentrism in global modern thought, see Mohammed Arkoun (2000). Present Day Islam between Its Tradition and Globalization. In: Farhad Daftary, ed., Intellectual Tradition in Islam, London: I.B. Tauris/Institute of Ismaili Studies, pp. 179-221. See other Muslim viewpoints on Islamic logocentrism and Arkoun's rationalist thought in, Usman Khalil and Abida Khan (2013). Islam and Postmodernity: M. Arkoun on Deconstruction. Journal of Islamic Thought and Civilization, Vol. 3 (1) online: http://admin.umt.edu.pk/Media/Site/ UMT/SubSites/jitc/FileManager/JITC\%2oSpring\%202013/2.\%2OIslam\%2oand\%2oPostmodernity. pdf.

36 Simon O'Meara (2020). The Ka'ba Orientations, Readings in Islam's Ancient House. Edinburgh: Edinburgh University Press.

37 Fourth paragraph of this unpaginated short presentation of logocentrism.

38 See Hamid Dabashi (2000). In: the Absence of the Face. Social Research 67 (1), pp. 127-85. In: the context of Judaic logocentrism see, Terje Stordalen (2016). Imagining Solomon's Temple: Aesthetics of the Non-Representable. In: Birgit Meyer and Terje Stordalen eds, Figurations and Sensations of the Unseen in Judaism, Christianity and Islam: Contested Desires, London: Bloomsbury Academic, pp. 21-36.

39 See Fahmida Suleman, ed. (2003). Word of God, Art of Man, The Qur'an and its Creative Expression. Oxford: Oxford University Press, London: The Institute of Ismaili Studies.

40 For example, while Shalem and Troelenberg (2010) rightly underscore the remarkable flourishing of ornament in Umayyad art, in particular in plastic spaces traditionally used to host figures, like arcade designs, and now filled with patterns, they systematically lend a representational or narrative quality to all genres of Umayyad iconography.

41 Finbarr B. Flood (1997). Umayyad Survivals and Mameluk Revivals: Qalawunid Architecture and the Great Mosque of Damascus. Muqarnas 14, p. 70.

42 Nadia Ali (May 2017). The royal veil: early Islamic figural art and the Bilderverbot reconsidered. Religion 47 (3), pp. 425-44.

43 See, Jas Elsner (2004). Late Antique Art: The Problem of the Concept and the Cumulative Aesthetic. In: Simon Swain and Mark Edwards eds., Approaching Late Antiquity: The Transformation from Early to Late Empire, Oxford: Oxford University Press, pp. 271-309; Slobodan Ćurčić (2011). Aesthetic Shifts in Late Antique Art: Abstraction, Dematerialization, and Two-Dimensionality. In: Anastasia Lazaridou, ed., Art of Late Antiquity, 3 rd-7th Century AD, New York: Onassis Foundation, pp. 67-73; and John R. Clarke (2006). Art in the Lives of Ordinary Romans, Visual Representation and Non-Elite Viewers in Italy. Oakland: University of California Press.

44 Jacques Rancière (2013). The Politics of Aesthetics. Translated by Gabriel Rockhill, London, New Delhi, New York, Sydney: Bloomsbury Academic, p. xiv.

45 This type of interpretation can be found in Shalem and Troelenberg (2010), for whom the status of ornament in the Umayyad period is elevated through the acquisition of a new power of iconicity, discursivity, and symbolization assimilable to representation, especially the vegetal motifs imbued with a quasi-natural force expressing the triumph of Islam, pp. 65-72; Priscilla Soucek (1993). "Solomon's Bath/Solomon's Throne: Model or Metaphor?" Ars Orientalis Vol. 23, pp. 109-34; and Hana Taragan (2019). Textiles in Cross-Cultural Encounters: The Case of the Umayyad Palace at Khirbat al-Mafjar. Al-Masāq Vol. 31, p. 16.

46 See Rafi Grafman and Myriam Rosen-Ayalon (1999). The Two Great Syrian Umayyad Mosques: Jerusalem and Damascus. Muqarnas 16, pp. 1-15; and for all the details about the mosque in the 
primary sources, see Finbarr B. Flood (2001). The Great Mosque of Damascus, Studies on the Making of an Umayyad Visual Culture. Leiden: Brill.

See Simon O’Meara (2019). Haptic Vision: Making Surface Sense of Islamic Material Culture. In: Robin Skeates and Jo Day, eds., The Routledge Handbook of Sensory Archaeology, London, New York: Routledge, pp. 467-80.

48 See Alain George (2017). Paradise or Empire, On a Paradox on Umayyad Art. In: Alain George and Andrew Marsham, eds., Power, Patronage and Memory in Early Islam: Perspective on Umayyad Elite, Oxford: Oxford University Press, pp. 39-67; Robert Hillenbrand (2012). Reflections on the Mosaics of the Umayyad Mosque in Damascus. In: Arabia, Greece and Byzantium, Cultural Contacts in Ancient and Medieval Times. Riyadh: King Fahad National Library Publications, pp. 163-87; Finbarr B. Flood (2001), pp. 57-79; Nasser Rabbat (1989). The Meaning of the Umayyad Dome of the Rock. Muqarnas 6, pp. 12-21, and (1997). The Mosaics of the Qubba al-Zahiriyya in Damascus: A Classical Syrian Medium Acquires a Mamluk Signature. Aram Periodical, pp. 1-14; and Oleg Grabar (1996). The Shape of the Holy, Islamic Jerusalem. Princeton: Princeton University Press.

49 Excerpted from Rabbat (1997), p. 9.

50 Excerpted from Ross Burns (2005). Damascus: A History. London, New York: Routledge, pp. 131-2.

51 See Fr. Michele Piccirillo (1993). Mosaics of Jordan. Amman, Jordan: American Center of Oriental Research. I thank Anna Contadini for mentioning this work to me.

52 Gilles Deleuze and Felix Guattari (2013). A Thousand Plateaus, Capitalism and Schizophrenia. Translated by Brian Massumi. London, New Delhi, New York, Sydney: Bloomsbury Academic, p. 116.

53 Will Schrimshaw (2019). Immanence and Immersion, On the Acoustic Condition in Contemporary Art. New York, London: Bloomsbury Academic, p. $5^{2}$.

54 Grabar (1996), p. 116.

55 About this reluctant scholarship see again Flood (2017-8).

56 See Judd (1975), “Jackson Pollock (1967)," p. 195.

57 Mosaics were used in Abbasid Samarra, but not after the city's fall. The tenth-century mosaics in the Umayyad Mosque of Cordoba emulate Syrian Umayyad art, but this art equally disappeared after the Andalusian caliphate's demise. As for the brief Mameluk revival of the Umayyad mosaic aesthetic in the thirteenth century, it constitutes an isolated episode of antiquarianism.

$5^{8}$ See Claire Bishop, ed. (2009), Participation, Documents of Contemporary Art. London: Whitechapel Gallery, Cambridge, MA: MIT Press.

59 I demonstrated this participatory phenomenon in my study of the Alhambra, in Valerie Gonzalez (2018). The Hermeneutics of Islamic Ornament: The Example of the Alhambra. In: Sabine Schmidtke, ed., Studying the Near and Middle East at the Institute of Advanced Study, Princeton, 1935-2018, Piscataway, NJ: Gorgias Press, pp. 375-88.

6o Roland Barthes (1970). Writing Degree Zero. Translated by Annette Lavers and Colin Smith. Boston: Beacon Press Books, p. 77 .

61 Ibid., p. 77.

62 Gernot Böhme (2017). Atmospheric Architectures, The Aesthetic of Felt Spaces. London: Bloomsbury Academic. See also Reza-Shah Kazemi (2003). Divine Beatitude: Supreme Archetype of Aesthetic Experience. In: Barry McDonald, ed., Seeing God Everywhere, Essays on Nature and the Sacred. Bloomington, IN: World Wisdom, pp. 215-26. 